Andréia Rodrigues Neves

\title{
Efeito da Temperatura Febril sobre o Fenótipo e Função de Células Dendríticas Derivadas de Monócitos Sanguiíneos
}

Tese apresentada ao Instituto de Ciências Biomédicas da Universidade de São Paulo, para obtenção do Título de Doutor em Ciências (Imunologia). 


\section{Andréia Rodrigues Neves}

\section{Efeito da Temperatura Febril sobre o Fenótipo e Função de Células Dendríticas Derivadas de Monócitos Sanguiíneos}

Tese apresentada ao Instituto de Ciências Biomédicas da Universidade de São Paulo, para obtenção do Título de Doutor em Ciências.

Área de Concentração: Imunologia

Orientador: Prof. Dr. José Alexandre Marzagão Barbuto 
DADOS DE CATALOGAÇÃO NA PUBLICAÇÃO (CIP)

Serviço de Biblioteca e Informação Biomédica do

Instituto de Ciências Biomédicas da Universidade de São Paulo

C reprodução total

Neves, Andréia Rodrigues.

Efeito da temperatura febril sobre o fenótipo e função de células dendríticas derivadas de monócitos sangüíneos / Andréia Rodrigues Neves. -- São Paulo, 2008.

Orientador: José Alexandre Marzagão Barbuto.

Tese (Doutorado) - Universidade de São Paulo. Instituto de Ciências Biomédicas. Departamento de Imunologia. Área de concentração: Imunologia. Linha de pesquisa: Células dendríticas.

Versão do título para o inglês: Effect of fever-range temperature on monocyte-derived dendritic cell phenotype and function.

Descritores: 1. Células dendríticas 2. Endotoxina bacteriana 3 . Febre 4. Hipertermia 5. Moléculas coestimuladoras 6. I. Barbuto, José Alexandre Marzagão II. Universidade de São Paulo. Instituto de Ciências Biomédicas. Programa de Pós-Graduação em Imunologia. III. Título. 


\section{UNIVERSIDADE DE SÃO PAULO \\ INSTITUTO DE CIÊNCIAS BIOMÉDICAS}

Candidato(a): $\quad$ Andréia Rodrigues Neves.

Título da Tese: $\quad$ Efeito da temperatura febril sobre o fenótipo e função de células dendríticas derivadas de monócitos sangüíneos.

Orientador(a): José Alexandre Marzagão Barbuto.

A Comissão Julgadora dos trabalhos de Defesa da Tese de Doutorado, em sessão pública realizada a ..................., considerou

\section{( ) Aprovado(a) ( ) Reprovado(a)}

Examinador(a): Assinatura:

Nome:

Instituição:

Examinador(a): Assinatura:

Nome:

Instituição:

Examinador(a): Assinatura:

Nome:

Instituição:

Examinador(a): Assinatura:

Nome:

Instituição:

Presidente: Assinatura:

Nome:

Instituição: 


\section{PARECEA SSIREP}

Freada Serhora

Atendendo sua soldtepba, a Comissto de tica em Fesulsas com Seres Humanos do $k \mathrm{CB}$, em sue quadrageimo pimetro reunlos, analsou a projeto de

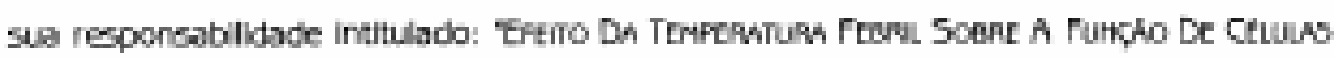

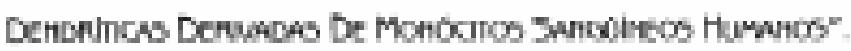

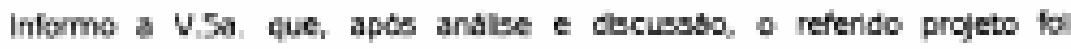
aprousdo por enta Combsio.

Estarego a visu que dentro de 12 meses. rebuto do releido pajets deced ser encminhado a secresria doste ter.

Cordamente,

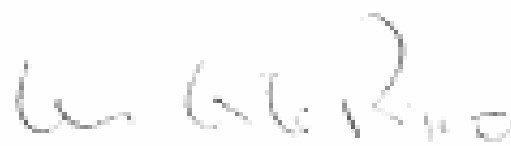

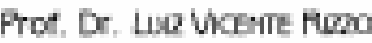

Coordenador da Corrissuo de tica ent

Pesqusas com Seres Humanos - kousp

Ima. $5 \mathrm{n}$

Ancrin Fooncus lievs

Departamento de Imunologla

Insuluto de qendas Blomdicas usp 
À minha família, pelo carinho, compreensão e o imenso apoio durante toda a minha vida. 


\section{AGRADECIMENTOS}

Ao meu orientador, Prof. Dr. José Alexandre M. Barbuto, pela sua orientação durante todos esses anos.

Aos professores Antonio Condino Neto, Maria Regina D’ Império Lima e Luciana de Deus V. Moraes pela participação em meu exame de qualificação e pelas preciosas sugestões para a continuidade de meu trabalho.

Aos amigos do laboratório de Imunologia de Tumores, pelo companheirismo, amizade e momentos divertidos. Agradeço por todo o apoio e pelas ricas discussões de idéias, que contribuíram muito para o meu crescimento e para o desenvolvimento deste trabalho.

Às minhas grandes amigas Camila, Marisa, Clara e Edimara, que além de me acompanharem por todo esse período, estiveram sempre ao meu lado nos momentos mais difíceis, sempre me apoiando e me dando força para que chegasse ao final. Amigas, sem dúvida, não conseguiria se vocês não estivessem comigo!

À professora Lourdes Isaac, pelo companheirismo, profissionalismo e exemplo de dedicação. Será eterna minha gratidão por seus ensinamentos e sua disposição em me ajudar.

Aos professores do Departamento de Imunologia. Levarei comigo uma parte de cada um como exemplos de grandes cientistas, professores e profissionais. Os conhecimentos que adquiri em todos esses anos serão incalculáveis na minha vida profissional e pessoal.

A todos os queridos amigos do Departamento de Imunologia. São tantos que não poderei nomeá-los. Muitos ainda continuam no ICB e outros já iniciaram 
uma nova etapa em suas carreiras. Mas todos eles foram muito importante, seja pelo companheirismo, pela amizade ou pelos momentos divertidos. Muito obrigada!

Aos funcionários Milton, Otacílio, Moisés e André pela atenção e paciência em nos ajudar sempre que preciso.

Ao pessoal da secretaria, Valéria, Jotelma, Eni e Amarildo, pela ajuda sempre que necessário.

Um agradecimento especial aos doadores de células mononucleares, pois sem eles este trabalho não poderia ter sido realizado.

Ao Banco de Sangue do Hospital Sírio Libanês, pela execução da leucoferese nos doadores voluntários.

À Capes e à Fapesp pelo apoio financeiro.

Em especial à minha família pelo grande apoio durante todos esses anos.

A todos os outros que, de alguma maneira, colaboraram para a realização desta tese. 
The great thing in this world is not so much where we stand, as in what direction we are moving. Oliver Homes, 1809-1894. 


\section{RESUMO}

NEVES, A.R. Efeito da Temperatura Febril sobre o Fenótipo e Função de Células Dendríticas Derivadas de Monócitos Sangüíneos. 2008. 83 f. Tese (Doutorado em Imunologia) - Instituto de Ciências Biomédicas, Universidade de São Paulo, São Paulo, 2008.

As células dendríticas (DCs) são as principais células apresentadoras de antígeno, responsáveis pelo início da resposta imune adquirida. Por outro lado, também exercem um importante papel na resposta inata, proporcionando uma ligação funcional entre esse dois aspectos da imunidade. Como componentes da resposta inata, é esperado que as DCs sejam suscetíveis a muitos sinais de ativação, os quais induzem diferentes padrões de ativação de DCs e, consequentemente, de resposta de linfócitos T. Neste trabalho, estudamos os efeitos de dois sinais de perigo reconhecidos pelo sistema imune inato, a febre e o LPS, sobre o fenótipo e função de DCs. Observamos que a exposição de DCs ao calor não afetou a expressão de CD80 e CD86, sua capacidade endocítica ou sua produção de citocinas, características que foram afetadas pelo LPS, conforme esperado. DCs expostas ao calor apresentaram uma maior atividade aloestimuladora e aumentada expressão de CD40. Quando DCs ativadas com LPS foram também estimuladas pelo calor, nenhuma alteração fenotípica na superfície celular foi observada, mas as DCs induziram maior produção de IFN-Y por linfócitos $T$ alogenêicos e favoreceram a proliferação de linfócitos T CD8+. Esses dados indicam que a febre pode favorecer uma resposta celular, através de sua ação sobre DCs ativadas, com provável participação do CD40. Além de seu significado fisiológico, esse fenômeno pode ter aplicação em estratégias imunoterapêuticas que utilizam DCs.

Palavras-chave: Células dendríticas. Febre. LPS. Hipertermia. Moléculas coestimuladoras. 


\begin{abstract}
NEVES, A.R. Effect of Fever-Range Temperature on Monocyte-Derived Dendritic Cell Phenotype and Function. 2008. 83 f. Doctoral Tese (Immunology) - Instituto de Ciências Biomédicas, Universidade de São Paulo, São Paulo, 2008.

Dendritic cells (DCs) are the main antigen presenting cells and, as such, key initiators of the acquired immune response. On the other hand, DCs also play a significant role in the innate response, thus providing a functional link between these two aspects of immunity. As components of the innate response it is not surprising that DCs are susceptible to many activation signals that will induce different patterns of DC activation and of T cell responses in consequence. In this work we studied the effects of two danger signals recognized by the innate immune system, fever and LPS, on DC phenotype and function. Exposure of immature monocyte-derived dendritic cells to heat did not affect CD80 and CD86 expression, their endocytic ability, or their cytokine production, characteristics that were affected by LPS, as expected. Heat-exposed DCs presented a higher allostimulatory activity and enhanced CD40 expression. When LPS activated DCs were also stimulated by heat, no cell surface phenotypic change was noted but these cells induced a higher IFN- $\gamma$ secretion by allogeneic $\mathrm{T}$ lymphocytes and favored the proliferation of $\mathrm{CD}^{+}$cells. These data indicate that fever may cause a bias toward cellular responses, through its action on activated DCs, probably through CD40. Besides its physiological meaning, this phenomenon may have applications in immunotherapeutic strategies using DCs.
\end{abstract}

Key words: Dendritic cells. Fever. LPS. Hyperthermia. Costimulatory molecules. 


\section{LISTA DE ILUSTRAÇÕES}

Figura 1: Expressão de moléculas de superfície ao final da cultura de células dendríticas.

Figura 2: Período de Estimulo com Temperatura Febril........................................34

Figura 3: Rendimento Final da Cultura de DCs......................................................36

Figura 4: Viabilidade celular analisada por incorporação de iodeto de propídeo.

Figura 5: Análise da expressão de moléculas coestimuladoras na superfície de células dendríticas estimuladas somente com temperatura febril.

Figura 6: Análise da expressão de moléculas coestimuladoras na superfície de células dendríticas co-estimuladas com LPS e temperatura febril.

Figura 7: Análise da expressão de moléculas coestimuladoras na superfície de células dendríticas.

Figura 8: Capacidade endocítica das Células Dendríticas.

Figura 9: Avaliação de Produção de Citocinas por DCs ao Final da Cultura. 45

Figura 10: Atividade aloestimuladora de células dendríticas .47

Figura 11: Sub-populações de linfócitos $T$ alogenêicos estimuladas por DCs.

Figura 12: Produção de citocinas em co-culturas alogenêicas de células dendríticas submeticas às diferentes condições de cultura e linfócitos $\mathrm{T}$ alogenêicos.

Figura 13: Produção de citocinas em co-culturas alogenêicas de células dendríticas submetidas às diferentes condições de cultura e linfócitos $\mathrm{T}$ alogenêicos.

Figura 14: Análise da expressão HSP70 na superfície de células dendríticas. 


\section{LISTA DE ABREVIATURAS E SIGLAS}

APC Célula apresentadora de antígeno

DC Célula dendrítica

MLR Reação mista leucocitária

CD Cluster de diferenciação

TLR Receptor tipo Toll

LPS Lipopolissacarídeo / Endotoxina bacteriana

CCR7 Receptor

IL Interleucina

TNF Fator de necrose tumoral

MCP Proteína quimiotática do monócito

IFN Interferon

CPDA Anticoagulante citratado

DNA Ácido desoxirribonucleico

HLA-DR Antígeno leucocitário humano - DR

AET 2-aminoethylisothiouronium bromide hydrobromide

SRBC Eritrócitos de carneiro

PBS Tampão salina fosfato 
CFSE Carboxifluoresceina diacetato succinimidil éster

BSA Albumina bovina sérica

FITC Isotiocianato de fluoresceína

PE Ficoeritrina

Cy CyCromo

GM-CSF Fator estimulante de colônias de macrófagos e granulócitos

MFI Média da intensidade de fluorescência

PAMP Padrão molecular associado a patógeno 


\section{SUMÁRIO}

1 INTRODUÇÃO

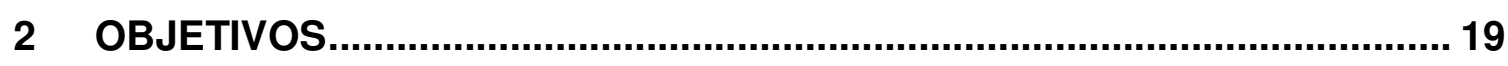

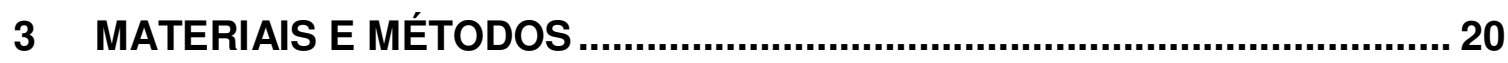

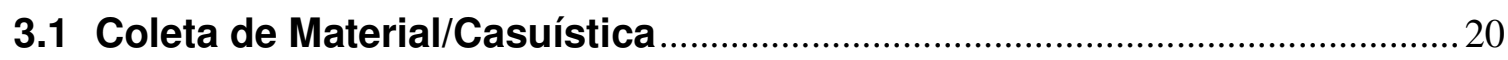

3.2 Diferenciação de células dendríticas a partir de monócitos do sangue periférico in vitro

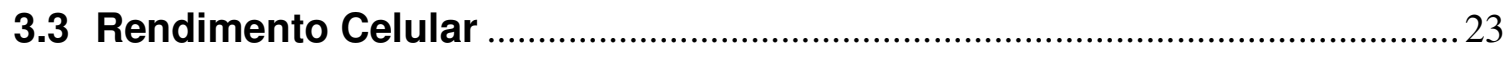

3.4 Determinação de Morte Celular ……………………………………………......2

3.5 Análise de moléculas de superfície por Citometria de Fluxo .......................23

3.6 Separação de linfócitos T para ensaio proliferativo. ........................................2

3.7 Avaliação da atividade aloestimuladora das DCs ……………………….....26

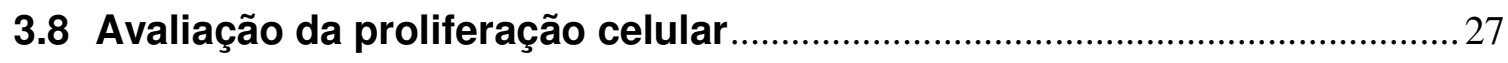

3.9 Detecção da produção de citocinas por ensaio imunoenzimático

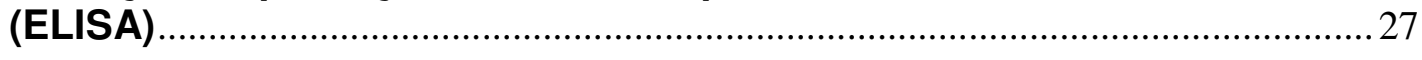

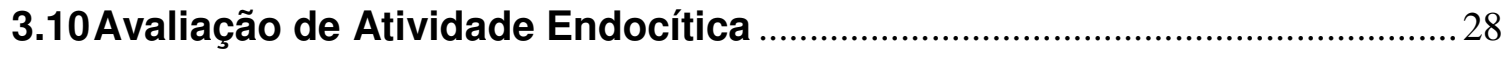

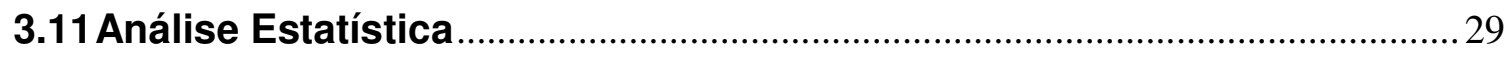

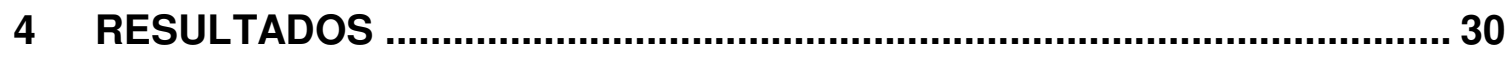

4.1 Caracterização de Células Dendríticas ............................................................... 30

4.2 Definição do Período de Estímulo Febril …………………………………........33

4.3 Rendimento Final da Cultura e Viabilidade Celular ...........................................35

4.4 Efeito da temperatura sobre a expressão de moléculas coestimuladoras na superfície de células dendríticas. ……………………………………........38

4.5 Efeito da temperatura sobre a capacidade endocítica de células dendríticas 
4.6 Secreção de TNF- $\alpha$, IL-10 e IL-12p70 por DCs cultivadas sob temperatura febril

4.7 Efeito da temperatura febril sobre a atividade aloestimuladora de células dendríticas

4.8 Efeito da Temperatura Febril sobre a Produção de Citocinas em Coculturas Alogenêicas

4.9 Análise da Expressão de Heat Shock Protein (HSP) - 70 na Superfície Celular de Células Dendríticas......................................................................52

5 DISCUSSÃO

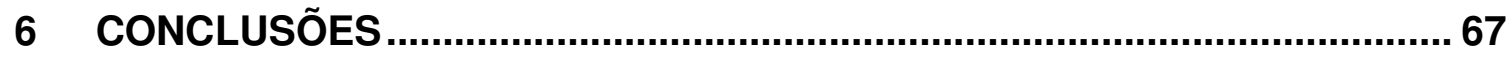

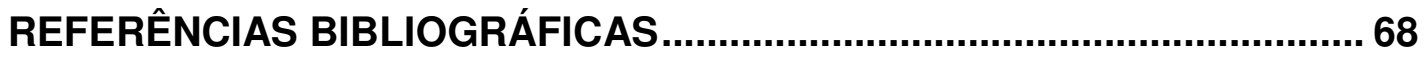

ANEXO 


\section{INTRODUÇÃO}

Em 1973, Ralph M. Steinman e Zanvil A. Cohn descreveram a identificação de um novo tipo celular em órgãos linfóides de camundongos (STEINMAN e COHN (1973, 1974a, 1974b); STEINMAN et al., 1974). Esta célula, assim como outros leucócitos mononucleares, possuía diversas organelas, tais como um grande número de mitocôndrias, endossomos de várias densidades e núcleo irregular. Entretanto, ela diferia das outras células encontradas nos órgão linfóides devido à presença de extensões citoplasmáticas arranjadas na forma de dendritos, que variavam em tamanho, forma e número. Devido a essas características morfológicas, elas foram denominadas células dendríticas (DCs) por seus descobridores (QUAH e O'NEILL, 2005; STEINMAN et al., 1974; STEINMAN e COHN (1973, 1974a, 1974b);).

Estudos subseqüentes, também realizados em camundongos, demonstraram que as DCs derivadas de baço poderiam ser 100 vezes mais efetivas do que macrófagos ou células mononucleares totais em estimular reações leucocitárias mistas (MLR) alogenêicas primárias (STEINMAN e WITMER, 1978) e em iniciar uma resposta MLR singenêica primária (NUSSENZWEIG e STEINMAN, 1980). A constatação desta importante capacidade funcional, em conjunto com outras investigações acerca desse tipo celular, permitiu a caracterização inicial da célula que é agora conhecida como a mais importante célula apresentadora de antígeno (APC) (BANCHEREAU et al., 2000). Mesmo após 25 anos desde sua descoberta, a capacidade de ativar linfócitos $T$ naïve é descrita como a principal característica funcional das DCs e o que definitivamente a distingue das outras populações celulares presentes no baço ou em outros órgãos do sistema imune (BANCHEREAU et al., 2000).

DCs imaturas estão estrategicamente localizadas em tecidos que representam rotas de entrada de patógenos (como a pele e a superfície mucosa), onde elas monitoram continuamente o ambiente através da internalização de partículas e produtos solúveis (BANCHEREAU e STEINMAN, 1998; 
BANCHEREAU et al., 2000). Células dendríticas maduras também podem ser encontradas na circulação sangüínea e linfática, com uma população que representa principalmente DCs em processo de emigração dos órgãos periféricos para os órgãos linfóides secundários (HART, 1997). Entretanto, embora esse conjunto de células seja denominado de células dendríticas, evidências experimentais obtidas no decorrer da última década mostraram que a população de DCs compreende uma extensa coleção de subpopulações, localizadas em órgãos linfóides e não-linfóides, e que estão relacionadas a funções específicas. Um dos principais problemas que envolvem a caracterização das DCs é a definição das vias de desenvolvimento que levam à geração dessas diferentes subpopulações (ARDAVIN et al., 2001; DEL HOYO et al., 2002; LEON; ARDAVIN, 2008). Além do mais, a distinção entre essas vias de desenvolvimento e as diferentes subpopulações é mais evidente em camundongos do que em humanos, principalmente devido à maior acessibilidade aos diferentes tecidos em modelos animais.

Dados resultantes de diferentes estratégias experimentais estabeleceram que as DCs murinas podem ser geradas de progenitores hematopoiéticos mielóides ou linfóides, embora alguns estudos contestem essa informação alegando que se trata de uma mesma população em diferentes estágios de desenvolvimento ou sob diferentes influências ambientais (ARDAVIN et al., 2001; DEL HOYO et al., 2002) Em humanos essa distinção é ainda menos clara do que no modelo murino e poucos estudos descrevem as diferentes subpopulações de DCs humanas. Em alguns poucos estudos realizados com DCs isoladas de órgãos linfóides humanos (timo e baço), pôde-se evidenciar uma grande heterogeneidade na expressão de CD4, CD11b e CD11c pelas DCs, mostrando a complexidade de caracterização destas células (MCILROY et al., 1995; VANDENABEELE et al., 2001). Pesquisas realizadas nos últimos anos têm buscado uma melhor descrição e caracterização das subpopulações de DCs, mas os mecanismos que controlam sua diferenciação e recrutamento ainda são estão inteiramente entendidos (MACDONALD et al., 2002; ARDAVIN, 2005; DUBSKY et al., 2005; RANDOLPH; OCHANDO; PARTIDA-SANCHES, 2008; PULEDRAN; TANG; DENNING, 2008). 
De maneira semelhante à caracterização das diferentes subpopulações de DCs, a determinação de seu estágio funcional ainda permanece bastante complexa (TAN e O’NEILL, 2005). O paradigma para a classificação de DCs conforme sua função é de que DCs residentes em tecidos não-linfóides em um estado de homeostasia são chamadas de imaturas e estão principalmente envolvidas na captura e processamento do antígeno (BANCHEREAU et al., 2000; GUERMONPREZ et al., 2002). Estas células expressam uma grande variedade de receptores que podem reconhecer de maneira específica moléculas relacionadas a patógenos, como por exemplo, os receptores do tipo Toll, TLR-2, TLR-3, TLR-4, TLR-5, TLR-8 e TLR-9, que reconhecem diversos tipos de moléculas, incluindo lipoproteínas, glicolipídeos, flagelinas e LPS (MUZIO et al., 2000; VISINTIN et al., 2001; HOCHREIN H e O'KEEFFE, 2008). Uma outra importante classe de receptores expressos por DCs são as lectinas do Tipo C, como o receptor para manose, DEC205 e DC-SIGN, que reconhecem estruturas de carboidratos nos patógenos (ENGERING et al., 1997; KATO et al., 2000; TAILLEUX et al., 2003; VAN VLIET; GARCIA-VALLEJO; VAN KOOYK, 2008).

Por outro lado, DCs que atingem a capacidade de migrar para órgãos linfóides secundários e de estimular linfócitos T são denominadas maduras (TAN e O’NEILL, 2005; RANDOLPH; OCHANDO; PARTIDA-SANCHÉZ, 2008). A maturação de DCs está associada a uma redução de sua capacidade endocítica, aumento na produção de citocinas inflamatórias e aquisição da capacidade de migração, principalmente através da expressão do receptor CCR7, para quimiocinas constitutivas do linfonodo (YANAGIHARA et al., 1998; GUERMONPREZ et al., 2002; VILLABLANCA; RUSSO; MORA, 2008) e a perda dos receptores CCR5 e CCR6, para quimiocinas inflamatórias (CAUX et al., 2000; VILLABLANCA; RUSSO; MORA, 2008). Tal alteração permite que as DCs que capturaram antígenos dirijam-se aos tecidos linfóides, mais especificamente para as áreas de células T, onde são capazes de recrutar outras DCs e linfócitos, através da liberação de quimiocinas (ADEMA et al., 1997; SOZZANI et al., 1998; SALLUSTO et al., 1999; VILLABLANCA; RUSSO; MORA, 2008). Além disso, a maturação de DCs também é caracterizada pelo aumento da expressão de 
moléculas classe II codificadas pelo complexo principal de histocompatibilidade (MHC II, ou HLA-DR em humanos) e de moléculas coestimuladoras (como o CD80, CD86 e CD40) na superfície destas células, que as tornam capazes de ativar de forma efetiva linfócitos T naïve ou de memória (CAUX et al.,1994; BANCHEREAU et al., 2000).

Pode-se observar, portanto, que a caracterização das DCs na literatura é bastante heterogênea e complexa e seus mecanismos de atuação e desenvolvimento ainda não estão totalmente esclarecidos. Contudo, o preciso entendimento destas células é importante, pois, devido a sua grande capacidade de estimulação, as DCs podem ser usadas em diversas estratégias terapêuticas para aumentar a resposta imune, como por exemplo, em protocolos de vacinação contra diversas doenças, inclusive câncer (BARBUTO et al., 2004; NEVES et al., 2005; YU et al., 2005). Além disso, acredita-se que as DCs também estejam envolvidas na escolha entre imunidade e tolerância, o que também pode ser importante no desenvolvimento de estratégias terapêuticas para doenças autoimunes e transplantes (BELZ et al., 2002; TAN e O'NEILL, 2005; RESCHNER et al., 2008).

Devido a essa ampla possibilidade de utilização em protocolos terapêuticos, as DCs têm sido extensivamente estudadas, seja em humanos, modelos animais ou in vitro (HSU et al., 1996; NESTLE et al., 1998; BROSSART et al., 2001; SCHENDEL, 2007; ZHANG, et al., 2007). Interessantemente, embora muitas condições de cultura tenham sido investigadas, somente nos últimos anos a influência do aumento da temperatura na resposta induzida pelas células dendríticas vem recebendo atenção (HUANG et al., 1996; OSTBERG et al., 2001; TOURNIER et al., 2003; HATZFELD-CHARBONNIER et al., 2007). Tal situação ocorre a despeito da função crucial das DCs na transição entre resposta imune inata e adaptativa, assim como da provável associação temporal de sua atividade com a elevação da temperatura, seja ela localmente, no caso da inflamação, ou sistêmica, no caso da resposta febril (REIS E SOUSA, 2004; OSTBERG e REPASKY, 2006) 
A elevação da temperatura no sítio de inflamação e a febre sistêmica são alguns dos mais freqüentes sinais clínicos encontrados em doenças, especialmente quando se trata de doenças infecciosas (KLUGER et al., 1975; JIANG et al., 2000). Além disso, a febre é uma resposta fortemente conservada evolutivamente e, em animais ectotérmicos, está associada a uma maior sobrevivência e encurtamento da doença durante as infecções (KUGLER et al., 1975; COVERT et al., 1977; BERNHEIM et al., 1978). Muito se sabe a respeito dos mediadores inflamatórios envolvidos na geração da febre (KLUGER, 1991; OSTBERG et al., 2000). As alterações morfológicas ocorridas na febre são mediadas por elevações sistêmicas ou locais de citocinas inflamatórias, como TNF- $\alpha$, IL-6 e IL-1 $\beta$, que são liberadas por plaquetas, neutrófilos ou macrófagos estimulados pelo microambiente local em resposta a um dano ou infecção. A IL-1 $\beta$ e o TNF- $\alpha$ estimulam o estroma e o endotélio a liberar uma segunda onda de TNF, IL-6 e IL-1 $\beta$, assim como IL-8 e MCP. Além de atuar na indução da síntese de proteínas de fase aguda, as citocinas TNF- $\alpha$, IL-6 e IL-1 $\beta$ também são pirógenos endógenos e afetam o mecanismo de regulação da temperatura no hipotálamo (BAUMANN e GAULDIE, 1994; OSTBERG et al., 2000).

Apesar dos diversos estudos que identificaram os eventos que causam a febre, o propósito biológico para o aumento da temperatura corpórea e o efeito específico que ela pode ter sobre os componentes efetores da resposta imune ainda são muito pouco entendidos, principalmente devido à dificuldade em separar os efeitos causados pela elevação da temperatura dos outros eventos neurológicos e fisiológicos que ocorrem durante a febre (WANG et al., 1999). Ainda assim, é corrente a intervenção clínica neste fator, principalmente através do uso de antipiréticos e analgésicos durante o curso da infecção (CUDDY, 2004; WALSH e EDWARDS, 2006).

Nos últimos anos, alguns estudos investigaram os efeitos do aumento da temperatura sobre células do sistema imune. Huang et al. (1996) demonstraram que a cultura de células mononucleares do sangue periférico sob altas temperaturas, $39{ }^{\circ} \mathrm{C}$ a $42{ }^{\circ} \mathrm{C}$, provocou um aumento na proliferação celular, na 
presença ou ausência de mitógeno. Além disso, estas células também aumentaram sua produção de IFN- $\gamma$ quando cultivadas sob temperatura febril. Um outro estudo, realizado por Ostberg et al. (2003), sugere que células de Langerhans têm uma aceleração na maturação e emigração da pele em camundongos submetidos à hipertermia, confirmando a importância da temperatura febril para a iniciação da resposta imune. Tournier et al. (2003) mostraram que células dendríticas de camundongos ativadas com LPS e cultivadas sob temperatura febril apresentaram um aumento na produção de IL12p70, diminuição de IL-10, e maior atividade aloestimuladora do que células cultivadas à $37{ }^{\circ} \mathrm{C}$. Um estudo bastante recente, realizado por HatzfeldCharbonnier et al. (2007) demonstrou que em resposta ao estresse por calor, DCs maduras produziram altos níveis de IL-12p70, TNF-a e foram capazes de estimular linfócitos $T$ naïve a uma polarização Th1 em ensaios de proliferação alogenêica.

O conjunto desses dados dá suporte ao conceito de que pode haver uma função benéfica da hipertermia sobre o sistema imune, já que é bastante improvável que a resposta febril fosse conservada evolutivamente se não houvesse um valor na sobrevivência (OSTBERG; PATEL; REPASKY, 2000). Além disso, esses estudos também podem indicar que se tal elevação na temperatura for considerada um estresse fisiologicamente relevante, pode-se suspeitar que a temperatura febril tenha um potencial para direcionar ou modular a resposta imune.

Um fator que está intimamente associado à elevação da temperatura, e que poderia estar relacionado com a estimulação da resposta imune na febre, é a expressão das proteínas de choque térmico (HSP) (MOSELEY, 2000). Assim como a febre, as HSPs foram altamente conservadas durante a evolução e exercem funções essenciais, como facilitação da translocação de proteínas através da membrana e proteção de proteínas contra danos, por exemplo, a desnaturação pelo calor (CHIRICO; WATERS; BLOBEL, 1988). Uma outra função importante dessas proteínas é sua atuação sobre células do sistema imune, 
inclusive células dendríticas (BASU et al., 2000), sendo importante para sua diferenciação e maturação. As HSPs são atualmente interessantes candidatas como estímulo de DCs em estratégias de vacinação contra o câncer (PARDOLL, 2002). HSPs isoladas de tumores, entre elas as HSP70 e HSP110 estão naturalmente associadas a antígenos tumorais e induzem forte resposta citotóxica contra células neoplásicas (BASU et al., 2000; UEDA et al., 2004). Interessantemente, estas HSPs também são induzidas sob estresse pelo calor e um estudo feito por Wang e colaboradores mostrou que o potencial de vacinação da HSP110 aumentou quando o tratamento foi acompanhado de hipertermia (WANG; OSTBERG; REPASKY, 2001).

A origem do uso da hipertermia está relacionada a alguns dos primeiros relatos da imunoterapia, que constataram que toxinas bacterianas administradas a pacientes com câncer, para estimulação da resposta imune, resultavam na indução de uma febre elevada (NOESSNER, 2006). Investigações iniciais, realizadas por Busch e posteriormente por Coley ${ }^{1}$ (apud NOESSNER, 2006) sobre a indução intencional de febre e resposta inflamatória como tratamento para câncer podem ser consideradas a primeira "vacina" contra o câncer. Nestes trabalhos, pôde-se observar uma forte correlação entre a regressão do câncer com a febre alta, no paciente. Mais recentemente, diversos estudos demonstram que a hipertermia promove a indução de uma resposta citotóxica antitumoral, in vitro e in vivo (ITO et al., 2001; ATANACKOVIC et al., 2002). Embora alguns pesquisadores associem os efeitos da hipertermia a um aumento da imunogenicidade de células tumorais, possivelmente através do aumento da apresentação antigênica via MHC I (ITO et al., 2001), é possível que a elevação da temperatura também exerça um efeito antitumoral através da estimulação da maturação das DCs, como sugerido por nossos resultados preliminares e os da literatura (HUANG; HAEGERSTRAND; FROSTEGARD, 1996; OSTBERG et al., 2001; TOURNIER et al., 2003).

\footnotetext{
${ }^{1}$ NAUTS, H.C.; MACLAREN, J.R. Coley Toxins - the first century. Adv. Exp. Med. Biol., v. 267, p. 483500.
} 
Apesar de evidências que indiquem um possível papel da febre sobre a resposta imune e de sua ocorrência natural em associação a infecções ou outras doenças, a temperatura não é uma variável considerada em grande parte das estratégias terapêuticas de vacinação baseada em DCs (OSTBERG; PATEL; REPASKY, 2000). Além disso, os mecanismos envolvidos em um possível papel da febre sobre a indução da resposta imune ainda não estão esclarecidos (OSTBERG; PATEL; REPASKY, 2000). A elucidação desses mecanismos pode contribuir para o esclarecimento dos mecanismos de resposta às infecções, assim como para o delineamento de novas estratégias terapêuticas utilizando a hipertermia em combinação com a imunoterapia, para o tratamento de diversas doenças, inclusive o câncer.

Diante disso, o objetivo do presente estudo foi avaliar o efeito do aumento da temperatura sobre células dendríticas derivadas de monócitos sangüíneos humanos e investigar mecanismos que estariam envolvidos em uma possível modulação da resposta pela febre. Uma vez que o aumento da temperatura está frequentemente associado com outros fatores locais, tais como destruição do tecido ou presença de moléculas microbianas que sinalizam sinais de perigo às DCs, tais como lipopolissacarídeo gram-negativo bacteriano (LPS), nesse trabalho nós avaliamos os efeitos funcionais e fenotípicos da temperatura febril associada com a presença de LPS sobre DCs derivadas de monócitos humanos, in vitro. Para isso, DCs foram geradas a partir de monócitos de doadores saudáveis e expostas à temperatura febril com ou sem a adição de LPS. 


\section{OBJETIVOS}

O objetivo do presente trabalho foi investigar o efeito da temperatura febril sobre o fenótipo e função alo-estimuladora de células dendríticas. Especificamente, os seguintes parâmetros foram avaliados :

- Efeito da temperatura febril sobre a viabilidade de DCs estimuladas com temperatura febril e/ou LPS

- Expressão de moléculas coestimuladoras em DCs estimuladas com temperatura febril e/ou LPS

- Atividade endocítica de DCs estimuladas com temperatura febril e/ou LPS.

- Secreção das citocinas TNF- $\alpha$, IL-10 e IL-12p70 por DCs ao término da cultura de diferenciação/maturação.

- Atividade estimuladora das DCs sobre linfócitos alogenêicos, avaliando a população total e as subpopulações de linfócitos CD4 e CD8.

- Produção de citocinas em co-culturas de linfócitos e DCs estimuladas com temperatura febril e/ou LPS.

- Análise da expressão de Heat Shock Protein (HSP) - 70 na superfície celular de DCs estimuladas com temperatura febril e/ou LPS. 


\section{MATERIAIS E MÉTODOS}

\subsection{Coleta de Material/Casuística}

Células mononucleares do sangue periférico, utilizadas para a cultura, foram obtidas de 22 indivíduos normais (ou seja, sem alterações clínicas significativas), 15 homens e 7 mulheres, com idade entre 25 e 42 anos, através de leucoferese realizada no Banco de Sangue do Hospital Sírio Libanês, após consentimento por escrito dos doadores. A coleta das amostras, assim como o projeto de estudo foram aprovados previamente pelos Comitês de Ética em Pesquisa do Hospital Sírio Libanês e do Instituto de Ciências Biomédicas da Universidade de São Paulo.

As amostras foram coletadas em Solução de Cloreto de Sódio 0,9\% contendo Anticoagulante Citratado (CPDA) e o material obtido foi armazenado em uma bolsa plástica, conforme procedimento padrão do Banco de Sangue do Hospital Sírio Libanês. O material foi utilizado no mesmo dia da coleta.

Como critério de elegibilidade, foram considerados idade acima de 18 anos, peso maior que 50 quilos e sorologia negativa para exames realizados rotineiramente em Banco de Sangue.

O material utilizado neste estudo é o excedente da coleta realizada para o protocolo de vacinação de pacientes para tratamento de câncer (Vacinação de Células Dendríticas fusionadas com Células Tumorais) realizado no laboratório onde o presente projeto foi desenvolvido.

\subsection{Diferenciação de células dendríticas a partir de monócitos do sangue periférico in vitro}

Para a purificação de células mononucleares, $20 \mathrm{~mL}$ do produto de aferese de células mononucleares de sangue periférico foram colocados em tubos plásticos cônicos de $50 \mathrm{~mL}$, aos quais foram acrescentados, no fundo do tubo, 12 
$\mathrm{mL}$ de Ficoll-Paque (Amersham Pharmacia, Little Chalfont, Buckinghamshire, Reino Unido). O material foi centrifugado a $600 \mathrm{~g}$ por 30 minutos a $18{ }^{\circ} \mathrm{C}$ e a camada de células mononucleares formada foi retirada com o auxílio de uma pipeta Pasteur descartável e colocada em outro tubo plástico cônico de $50 \mathrm{~mL}$. $\mathrm{O}$ volume final foi completado com HBSS (Hanks Balanced Salt Solution - Gibco Life Technologies Grand Island, NY, EUA) e, após homogeneização, o tubo foi centrifugado a $240 \mathrm{~g}$ por $10 \mathrm{~min}$, para lavagem. Este procedimento foi repetido por mais 2 vezes, com centrifugações a $200 \mathrm{~g}$ e $190 \mathrm{~g}$, respectivamente, para eliminação das plaquetas. O "pellet" final foi coletado, as células quantificadas em câmara de Neubauer e ressuspendidas em meio RPMI-1640 (Sigma-Aldrich, St Louis, MO, EUA), suplementado com 10\% de Soro Fetal Bovino [Gibco Life Technologies Grand Island, NY, EUA]. As células foram plaqueadas em placas plásticas de 12 poços, sendo que cada poço continha um total de $5 \times 10^{6}$ células (aderentes + não aderentes) em $2 \mathrm{~mL}$ de meio RPMI-1640 (Sigma-Aldrich) suplementado com 10\% de Soro Fetal Bovino (Gibco Life Technologies ). As células foram mantidas por 2 horas em estufa com atmosfera contendo $5 \%$ de $\mathrm{CO}_{2}$ e saturada de água, a $37^{\circ} \mathrm{C}$, para aderência dos monócitos.

Após o período de aderência, as células não-aderentes foram desprezadas e as aderentes cultivadas em meio RPMI-1640, suplementado com 10\% de Soro Fetal Bovino e acrescido de $50 \mathrm{ng} / \mathrm{mL}$ de GM-CSF (Peprotech, Rocky Hill, NJ, EUA) e 50 ng/mL de IL-4 (Peprotech, Rocky Hill, NJ, EUA).

Determinação do período de cultura das células dendríticas sob temperatura febril.

Para avaliação do melhor período de estímulo com temperatura febril, as células dendríticas foram cultivadas à $37^{\circ} \mathrm{C}$ até o período final da cultura, quando elas foram transferidas para estufa à $39 \stackrel{\circ}{ } \mathrm{C}$. Para o período de testes preliminares, os períodos finais testados foram: últimas 2 horas, 12 horas, 24 horas e 48 horas. Para todos os períodos testados, o tempo total de cultura sempre foi de 7 dias. Diante dos resultados obtidos nos ensaios de proliferação alogenêica 
(apresentados em Resultados), o período final escolhido foi de 48 horas. A partir de então, toda a incubação com temperatura febril foi realizada com esse período.

Para a avaliação do efeito da temperatura febril em células não estimuladas e em conjunto com o estímulo por LPS (Escherichia coli), foram estabelecidas as seguintes condições de cultura:

- DCs não estimuladas: as células foram cultivadas por 7 dias em estufa à $5 \% \mathrm{CO}_{2}$, temperatura de $37^{\circ} \mathrm{C}$.

- DCs Febre: as células foram cultivadas por 5 dias em estufa $5 \% \mathrm{CO}_{2}$, à 37 $\stackrel{\circ}{ }{ }^{\circ}$. No $6^{\circ}$ dia, as células fora transferidas para estufa $5 \% \mathrm{CO}_{2}$, com temperatura à 39 ㄷ. Após um período de 48 horas sob esta temperatura, as células foram retiradas e submetidas às diferentes análises.

- DCs LPS: as células foram cultivadas por 7 dias em estufa $5 \% \mathrm{CO}_{2}$, com temperatura à $37^{\circ} \mathrm{C}$. No $6^{\circ}$ dia, as células foram estimuladas com $1 \mu \mathrm{g} / \mathrm{mL}$ de LPS (Escherichia coli) por um período de 18 horas ("overnight"). No $7^{\circ}$ dia, as células foram retiradas e analisadas.

- DCs LPS Febre: as células foram cultivadas por 5 dias em estufa $5 \% \mathrm{CO}_{2}$, com temperatura de $37^{\circ} \mathrm{C}$. No $5^{\circ}$ dia, as células foram transferidas para estufa à $39 \stackrel{\circ}{ } \mathrm{C}$. No $6^{\circ}$ dia, as células foram estimuladas com $1 \mu \mathrm{g} / \mathrm{mL}$ de LPS (Escherichia coli) por 18 horas (“overnight”). No $7^{\circ}$ dia, as células foram retiradas e analisadas.

Ao final do período de cultura, as células flutuantes ou fracamente aderentes foram retiradas, centrifugadas a $240 \mathrm{~g}$, por 8 minutos e ressuspensas em meio RPMI-1640 (Sigma-Aldrich) suplementado com 10\% de Soro Fetal Bovino (Gibco Life Technologies ). O sobrenadante de cultura foi armazenado para a realização de ensaio imunoenzimático (ELISA) para produção de citocinas, conforme descrito adiante. A viabilidade celular foi avaliada por contagem em Câmara de Neubauer, após coloração com Azul de Trypan (Sigma-Aldrich, St Louis, MO, EUA) 0,4\%, na proporção 1:1. 


\subsection{Rendimento Celular}

Para cálculo do rendimento celular final, foram consideradas as células vivas detectadas através de coloração por Azul de Trypan (Sigma-Aldrich) 0,4\%, 1:1. O rendimento final da cultura foi expresso em porcentagem pela relação:

Número de células vivas no final da cultura $\quad$ X 100

Número de células (aderentes + não aderentes) plaqueadas no início da cultura

\subsection{Determinação de Morte Celular}

Para a detecção de morte celular, além da coloração com Azul de Trypan (Sigma-Aldrich), foi utilizada a técnica de citometria de fluxo, para avaliar a porcentagem de fragmentação de DNA. A fragmentação de DNA foi calculada por análise do ciclo celular do conteúdo de DNA total, conforme descrito anteriormente, (NICOLETTI et al., 1991) com modificações. Para tanto, um máximo de $2 \times 10^{6}$ células foram centrifugadas a $240 \mathrm{~g}$ por 5 minutos $\mathrm{e}$ resssuspensas em $300 \mu \mathrm{l}$ de tampão hipotônico HFS (ANEXO). Em seguida, as células foram incubadas por um período mínimo de 4 horas a $4^{\circ} \mathrm{C}$. A análise foi feita por citometria de fluxo, sendo que o conteúdo de DNA produziu um perfil gráfico de acordo com a fase do ciclo celular em que as células se encontravam. As células em morte celular são identificadas como tendo núcleos hipodiplóides, os quais aparecem à esquerda do pico G0-G1.

\subsection{Análise de moléculas de superfície por Citometria de Fluxo}

Para determinação do fenótipo de membrana, células obtidas a partir das diferentes condições de cultura foram marcadas com anticorpos monoclonais comerciais (BD Pharmingen ${ }^{\mathrm{TM}}$, San Diego, CA, EUA) contra os marcadores: CD11c (marcador de DCs mielóides), CD40, CD80 e CD86 (B7-1 e B7-2, moléculas co-estimuladoras), HLA-DR (molécula apresentadora de antígeno) e CD14 (marcador de monócitos, ausente em DCs) e HSP-70 (proteína de choque térmico). A descrição detalhada dos anticorpos é mostrada na Tabela 1. 
Tabela 1: Anticorpos monoclonais específicos utilizados para a avaliação do fenótipo de membrana das células geradas.

\begin{tabular}{llll}
\hline Especificidade & Clone & Origem & Marcação \\
\hline CD11c & B-ly6 & IgG1, $k$ de camundongo & Cy \\
\hline HLA-DR & G46-6 $($ L243) & IgG2a, $k$ de camundongo & FITC \\
\hline CD14 & M5E2 & IgG2a, $k$ de camundongo & PE \\
\hline CD80 & L307.4 & IgG1, $k$ de camundongo & PE \\
\hline CD86 & 2331(fun-1) & IgG1, $k$ de camundongo & FITC \\
\hline CD40 & 5C3 & IgG1, $k$ de camundongo & PE \\
\hline HSP70 & C92F3A-5 & IgG1, $k$ de camundongo & PE \\
\hline
\end{tabular}

Análise das moléculas de superfície: Após contagem, alíquotas de $2 \times 10^{5}$ células obtidas das culturas foram colocadas em tubos plásticos (eppendorf, Westbury, NY, EUA) de $1,5 \mathrm{~mL}$ e centrifugadas por $5 \mathrm{~min}$, a $240 \mathrm{~g} \mathrm{e} 4{ }^{\circ} \mathrm{C}$ para obtenção de um "pellet", ao qual foram adicionados $50 \mu \mathrm{l}$ de soro humano AB para neutralização de receptores Fc não-específicos. Após 10 minutos de incubação, as células foram lavadas com tampão para citometria (ANEXO) e incubadas com anticorpos específicos para os marcadores de interesse. As células foram incubadas por 20 min a $4{ }^{\circ} \mathrm{C}$, no escuro. Após este período, o material foi lavado por 2 vezes ( $5 \mathrm{~min}, 240 \mathrm{~g}, 4^{\circ} \mathrm{C}$ ) com $500 \mu \mathrm{L}$ de tampão para citometria (ANEXO). Após as lavagens, as células, já marcadas, foram ressuspensas em $500 \mu \mathrm{L}$ de tampão para citometria. A aquisição e análise foram feitas em citômetro de fluxo (FACScalibur - Becton Dicknson, Palo Alto, CA, EUA), usando-se o software CellQuest (Becton Dicknson, Palo Alto, CA, EUA).

Para cada população foram avaliadas a porcentagem de expressão e a média da intensidade de fluorescência $(\mathrm{MFI})$ da expressão das moléculas marcadas. 


\subsection{Separação de linfócitos T para ensaio proliferativo.}

Obtenção de Células Não Aderentes do Sangue Periférico Humano: Para a separação de linfócitos $T$ alogenêicos, células mononucleares, obtidas do mesmo modo como já descrito anteriormente, foram incubadas em placas plásticas de 6 poços, por 2 horas, em estufa com atmosfera contendo $5 \%$ de $\mathrm{CO} 2$ e saturada de água, à $37 \stackrel{\circ}{\circ}$. Após esse período, as células não aderentes foram retiradas e incubadas com hemácias de carneiro pré-tratadas com AET (2aminoethylisothiouronium bromide hydrobromide; Sigma-Aldrich, St. Louis, MO, EUA), conforme descrito a seguir.

Preparação das hemácias de carneiro: As hemácias de carneiro para formação de rosetas com linfócitos $T$ alogênicos foram preparadas conforme descrito por Saxon, Feldhaus e Robins (1976). Para isso, as hemácias foram colocadas em um tubo plástico estéril de $50 \mathrm{~mL}$ e centrifugadas a $240 \mathrm{~g}$ durante 10 minutos a $20^{\circ} \mathrm{C}$, e a seguir lavadas 2 vezes, com mesma centrifugação, em tampão PBS (ANEXO). Estas hemácias foram tratadas com AET (2-aminoethylisothiouronium bromide hydrobromide; Sigma-Aldrich) para mudança da carga elétrica da superfície das hemácias, possibilitando uma maior interação eletrostática com linfócitos $T$ alogênicos e a formação de rosetas estáveis. Para tanto, foram diluídos $0,5 \mathrm{~g}$ de AET em 12,5 mL de água bidestilada e deionizada, com ajuste final do $\mathrm{pH}$ para 9,0 utilizando-se $\mathrm{NaOH}$ (Sigma-Aldrich, St. Louis, MO, EUA) 1,0 N. Após passagem em filtro de 0,22 $\mu \mathrm{m}$ (Millipore, Billerica, MA, EUA), $8 \mathrm{~mL}$ de solução de AET foram acrescentados a cada $2 \mathrm{~mL}$ de papa de hemácias de carneiro e mantidos durante 20 a 40 minutos a $37^{\circ} \mathrm{C}$.

A seguir, as hemácias foram lavadas (centrifugação a $290 \mathrm{~g}$ por 10 minutos, até obtenção de sobrenadante claro) com tampão PBS (ANEXO) $\mathrm{pH} 7,2$ e ressuspensas finalmente até se obter uma suspensão a 4\% em meio RPMI-1640 (Sigma-Aldrich), suplementado com 10\% de Soro Fetal Bovino (Gibco Life Technologies ). Esta suspensão (AET-SRBC: para $1 \mathrm{~mL}$ de papa - 20 a $25 \mathrm{~mL}$ de R10), foi guardada na geladeira por até 1 mês. 
Recuperação de linfócitos T: Uma suspensão de células não aderentes em concentração máxima de $1 \times 10^{7}$ células $/ \mathrm{mL}$ foi preparada, misturada com soro fetal bovino e hemácias de carneiro pré-tratadas com AET (preparação AET-SRBC), numa proporção de 1: 0,5:1, centrifugada a $200 \mathrm{~g}$, por 5 minutos a $4{ }^{\circ} \mathrm{C}$ e incubada em gelo por 1 hora. Após a incubação, as células foram novamente ressuspensas e o número de rosetas contado.

A suspensão foi então submetida à centrifugação em Ficoll-Paque (Amersham Pharmacia) (690 g, $4{ }^{\circ} \mathrm{C}, 35$ minutos). Após a centrifugação, os linfócitos T, presentes no "pellet", formando rosetas com as hemácias de carneiro modificadas, foram recuperados com tampão de lise de hemácias (ANEXO) e lavados em meio de cultura RPMI-1640 (Sigma-Aldrich) suplementado com 10\% de Soro Fetal Bovino (Gibco Life Technologies ), com centrifugação a $250 \mathrm{~g}$, durante 10 minutos a $20^{\circ} \mathrm{C}$. Os linfócitos T obtidos foram ressuspensos em $2 \mathrm{~mL}$ de meio RPMI-1640 (Sigma-Aldrich) suplementado com 10\% de Soro Fetal Bovino (Gibco Life Technologies ), quantificados em câmara de Neubauer, e sua concentração ajustada para $1,0 \times 10^{5}$ células $/ \mathrm{mL}$. Os linfócitos $\mathrm{T}$ obtidos foram utilizados em co-cultura com células dendríticas alogênicas, para avaliação de atividade aloestimuladora e produção de citocinas, conforme descrito nas próximas seções.

\subsection{Avaliação da atividade aloestimuladora das DCs}

Para avaliar a capacidade aloestimuladora das células geradas, $1 \times 10^{4}$ DCs irradiadas (1250 rads) (células estimuladoras) foram co-cultivadas com $1 \mathrm{x}$ $10^{5}$ células mononucleares alogêneicas (células respondedoras) em um volume final de $100 \mu \mathrm{L} /$ poço. A cultura foi realizada em placas de 96 poços, com fundo em U. As células foram mantidas por 6 dias em estufa com atmosfera contendo $5 \%$ de $\mathrm{CO}_{2}$ e saturada de água (estufa de $\mathrm{CO}_{2}$ ), a $37^{\circ} \mathrm{C}$. 


\subsection{Avaliação da proliferação celular}

Para avaliação da proliferação celular, um máximo de $1 \times 10^{7}$ células respondedoras foram incubadas em tampão PBS-BSA 0,1\% (ANEXO), contendo $5 \mu \mathrm{M}$ de CFSE (Molecular Probes, Eugene, OR, EUA), antes da co-cultura com DCs. A incubação foi feita à temperatura ambiente, no escuro, sob agitação por 15 min. Após este período, as células foram lavadas 2 vezes em meio RPMI, suplementado com $3 \%$ de Soro Bovino Fetal (Gibco Life Technologies). As células respondedoras foram, então, co-cultivadas com DCs, e ao final da cultura, a intensidade de fluorescência do CFSE (Molecular Probes) nas células respondedoras foi analisada em citômetro de fluxo (FACSCalibur - Becton Dickinson). Células em divisão, por definição, apresentam intensidade de fluorescência reduzida aproximadamente pela metade, em comparação às células que não se dividiram. Para avaliação da subpopulação de linfócitos em proliferação, as células foram marcadas, ao final da cultura com anticorpos antiCD4 e anti-CD8 (BD Pharmingen ${ }^{\mathrm{TM}}$ ), nas mesmas condições do item 4 acima. Além da análise da porcentagem total de células em proliferação, também se verificou a porcentagem de células que expressavam CD4 ou CD8 dentro desta população. Os dados obtidos foram analisados usando-se o "software" CellQuest (Becton Dicksinson).

\subsection{Detecção da produção de citocinas por ensaio imunoenzimático} (ELISA)

Para detecção de IL-10, IL-12p70 e TNF- $\alpha$ dos sobrenadantes das culturas de DCs e de IL-4, IL-10, IL-12p70 e TNF- $\alpha$ das co-culturas de DCs e linfócitos alogenêicos, utilizamos os kits BD OptEIA ${ }^{\mathrm{TM}}$ Human Set (BD Biosciences, San Diego, CA, EUA). Neste método, placas de 96 poços Maxisorp (Nunc, Rochester, New York, EUA) foram sensibilizadas com $50 \mu \mathrm{L}$ por poço de anticorpo de captura (na diluição 1:250, conforme especificado nas instruções do fabricante) para cada citocina, diluído em Tampão de Captura (ANEXO) e mantidas a $4 \stackrel{\circ}{ } \mathrm{C}$ "overnight". Após 3 lavagens com 300 $\mathrm{L}$ /poço de Tampão de Lavagem (ANEXO), as placas foram bloqueadas com $300 \mu \mathrm{L} /$ poço de Tampão de Diluição (ANEXO) por $2 \mathrm{~h}$ a 
temperatura ambiente. Em seguida, após 3 lavagens, as amostras e a curvapadrão foram incubadas por um período de 2 horas em temperatura ambiente. As amostras para dosagem foram diluídas 1:2 em Tampão de Diluição. Para a curvapadrão, as citocinas recombinantes foram incubadas em duplicatas de $50 \mu \mathrm{L}$ por poço das diluições seriadas (fator 2 de diluição), conforme recomendações do fabricante. O período de incubação das amostras e da curva padrão foi de 2 horas à temperatura ambiente. Após 5 lavagens, foram adicionados $50 \mu \mathrm{L} /$ poço de anticorpo de detecção (na diluição 1:250, conforme instruções do fabricante), em conjunto com o conjugado de peroxidade-estreptoavidina. Seguiu-se nova incubação por 1 hora à temperatura ambiente. Após esta etapa, a placa foi lavada 7 vezes e $50 \mu \mathrm{L} /$ poço de substrato $\left(\mathrm{H}_{2} \mathrm{O}_{2}\right.$ e "tetrametilbenzidina", na proporção de 1:1) foram adicionados, com incubação de, aproximadamente 20 minutos, no escuro, à temperatura ambiente. Por fim, $50 \mu \mathrm{L} /$ poço de $\mathrm{H}_{2} \mathrm{SO}_{4}(2 \mathrm{~N})$ foram adicionados para interromper a reação e a densidade óptica foi determinada em espectrofotômetro com filtro de $450 \mathrm{~nm}$. O cálculo das concentrações foi feito com auxílio do "software" Softmax Pro, através da equação de regressão linear com base na curva padrão e a análise de dados foi executada com auxílio do software Graphpad Prism 2.01.

\subsection{Avaliação de Atividade Endocítica}

Para a avaliação da atividade endocítica, as células obtidas ao final da cultura foram re-plaqueadas em placas de 24 poços em meio RPMI-1640 (SigmaAldrich) contendo 10\% de Soro Bovino Fetal (Gibco Life Technologies) e $1 \mathrm{mg} / \mathrm{mL}$ de Dextran-FITC (Sigma-Aldrich, St Louis, MO, EUA) e, incubadas em estufa 37 ○C por 1 hora. Após este período, as células foram lavadas duas vezes em meio de cultura RPMI-1640 (Sigma-Aldrich), com centrifugação de $240 \mathrm{~g}$ por 10 minutos. Para controle negativo (ligação inespecífica), as células foram incubadas com a mesma concentração de Dextran-FITC (Sigma-Aldrich) a $4 \stackrel{\circ}{\circ} \mathrm{C}$. A atividade endocítica foi avaliada, então, através de citometria de fluxo. Os resultados são mostrados como média geométrica da intensidade de fluorescência, ou seja, 
quanto maior a média geométrica, maior a incorporação de Dextran-FITC (SigmaAldrich) pelas células dendríticas.

\subsection{Análise Estatística}

Para a análise estatística, inicialmente, foi feito um teste de distribuição para avaliar se a distribuição era Gaussiana. Uma vez que os dados apresentaram distribuição normal, foi realizada a análise através de teste $T$ pareado, considerando os seguintes pares:

- DCs não estimuladas versus DCs Febre

- DCs LPS versus DCs LPS Febre

A única exceção foi a avaliação do rendimento celular nas diferentes condições de cultura, onde foi realizada análise de variância pelo teste ANOVA paramétrico, seguido do teste de Tukey, que compara todos os grupos entre si.

Considerou-se significância estatística quando o as análises apresentaram $\mathrm{p}<0,05$.

Todos os testes foram realizados com a ajuda do software GraphPad Prism 2.01 . 


\section{RESULTADOS}

\subsection{Caracterização de Células Dendríticas}

Células dendríticas derivadas de monócitos sangüíneos apresentam como características fenotípicas a expressão das moléculas CD11c (marcador de mielóide) e HLA-DR (molécula apresentadora de antígenos), ausência da expressão da molécula CD14 (marcador de linhagem monocítica) e expressão de moléculas coestimuladoras, como CD80, CD86 e CD40. Portanto, nossa primeira abordagem foi averiguar a expressão dessas moléculas nas células originadas ao final da cultura dos monócitos com GM-CSF e IL-4, que daqui por diante chamaremos de Células Dendríticas. Como comparativo, verificamos também a expressão dessas moléculas em monócitos sangüíneos cultivados pelo mesmo período, em meio de cultura semelhante, exceto pela ausência das citocinas diferenciadoras de células dendríticas (GM-CSF e IL-4).

Observamos que, diferente das células cultivadas sem as citocinas diferenciadoras (macrófagos), as células dendríticas, ao final da cultura, apresentavam-se não aderentes à placa de plásticos (dados não mostrados).

Para a caracterização fenotípica, delimitamos uma área (gate) excluindo regiões que consideramos debri celulares decorrentes do procedimento para citometria de fluxo, uma vez que, além de suas características de tamanho e granulosidade, constatamos não haver expressão de qualquer uma das moléculas analisadas.

Considerando a região analisada dentro do gate, foi possível verificar que cerca de $90 \%$ das células expressavam as moléculas CD11c e HLA-DR (Figura 1). Além disso, quando analisamos a expressão de moléculas coestimuladoras dentro desta população (CD11 $\left.\mathrm{C}^{+} \mathrm{HLA}-\mathrm{DR}^{+}\right)$observamos que as células dendríticas apresentavam expressão de CD86, CD40 e CD80 (Figura 1). Por outro lado, monócitos cultivados na ausência das citocinas diferenciadoras apresentam alta 
expressão da molécula CD14, baixa ou nenhuma expressão de moléculas coestimuladoras (Figura 1), além de forte aderência a placas de plásticos, de forma que não é possível sua retirada sem o auxílio de scrapper.

Em conjunto, as características apresentadas pelas células cultivadas em meio contendo GM-CSF e IL-4 correspondem às descritas para células dendríticas derivadas de monócitos sangüíneas. 

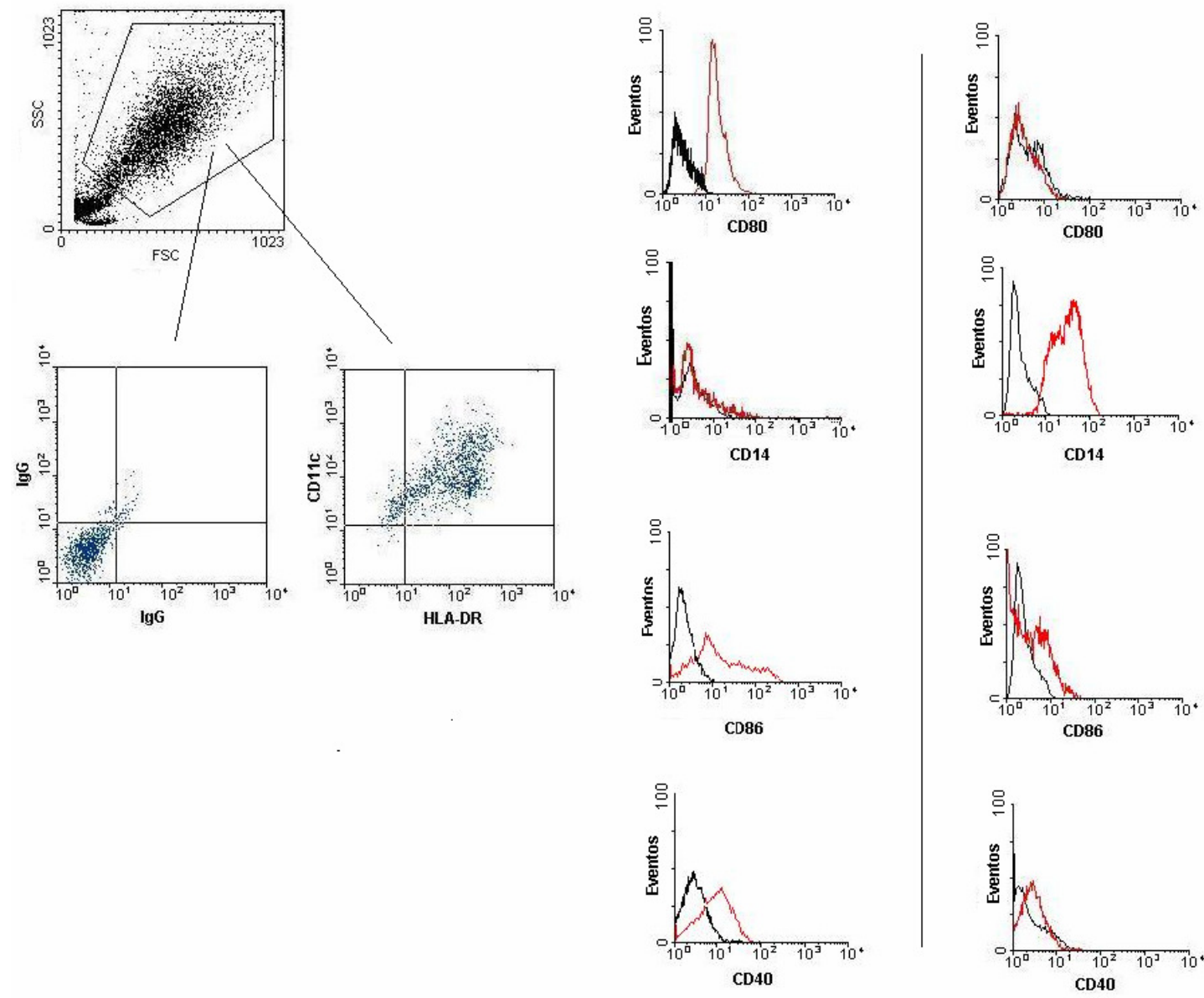

Células aderentes cultivadas com GM-CSFILL -4 (Células Dendríticas)

Macrófagos

Figura 1: Expressão de moléculas de superfície ao final da cultura de células dendríticas. Células mononucleares separadas por gradiente de Ficoll-Paque foram enriquecidas por aderência em Placa de Petri e cultivadas em meio RPMI na presença de GM-CSF e IL-4. Após a cultura, as células sempre foram marcadas com anticorpos para as moléculas de CD11c e HLA-DR, variando apenas a marcação do terceiro anticorpo (CD14, CD80, CD86 ou CD40). Macrófagos foram cultivados em mesmo meio, sem adição de GM-CSF e IL-4 e marcados com CD14, CD80, CD86 e CD40. As células foram analisadas em citômetro de fluxo. 


\subsection{Definição do Período de Estímulo Febril}

Experimentos iniciais realizados em nosso laboratório haviam indicado um possível efeito da temperatura febril sobre a proliferação alogenêica. Com o intuito de avaliar o efeito da temperatura febril sob as melhores condições, realizamos testes preliminares utilizando diferentes períodos de cultura sob temperatura a 39 ${ }^{\circ} \mathrm{C}$. Conforme demonstrado na figura 2 , observamos que o período que resultou em melhor resposta estimuladora alogenêica das células dendríticas foi o período de cultura por 48 horas, pois nos 3 experimentos preliminares realizados, células dendríticas sob essas condições foram capazes de induzir proliferação alogenêica superior às células dendríticas controles (DCs não estimuladas). Diante disso, essa condição foi escolhida para o estudo do efeito da temperatura sobre as DCs. 


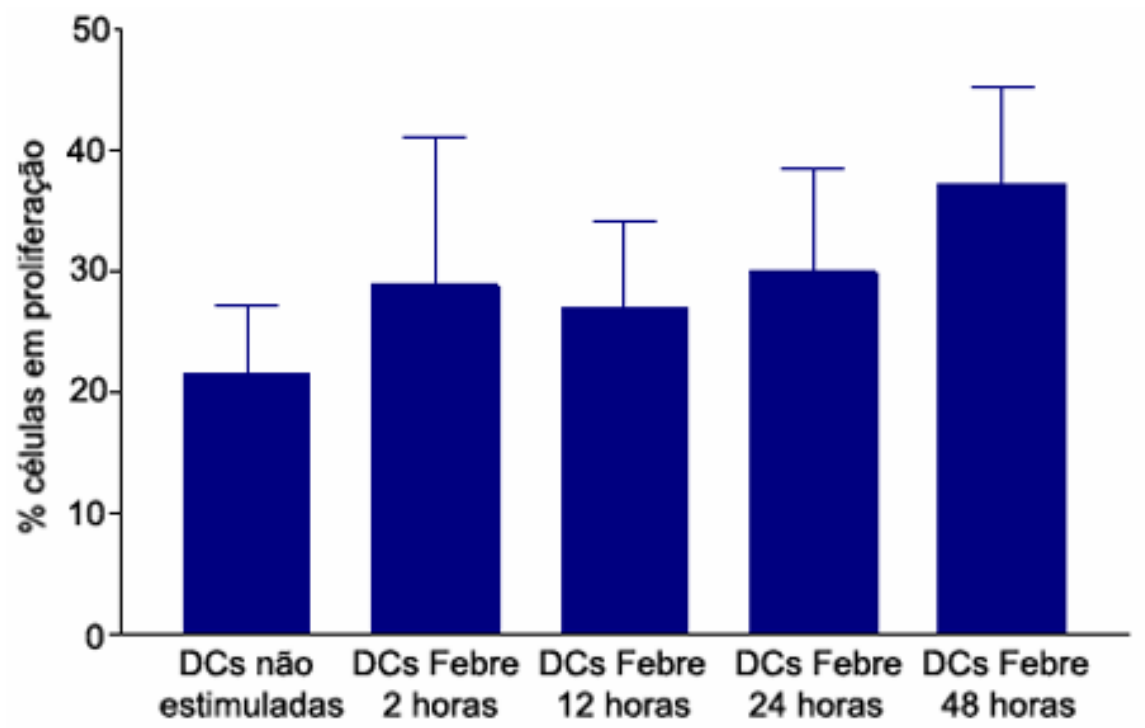

Figura 2: Período de Estimulo com Temperatura Febril. Células mononucleares foram cultivadas em presença de GM-CSF e IL-4 e cultivadas à $37^{\circ} \mathrm{C}$. Nas últimas horas (ou seja, 2horas, 12 horas, 24 horas ou 48 horas) as células foram transferidas para estufa à $39^{\circ} \mathrm{C}$ e permaneceram sob esta condição até 0 término da cultura. Ao final da cultura, as células foram retiradas, irradiadas e co-cultivadas com linfócitos T alogenêicos previamente incubados com CFSE. Ao final da co-cultura, as células não aderentes foram analisadas em citometria de fluxo para avaliar a diminuição da intensidade de fluorescência de CFSE (consideradas células em proliferação), conforme descrito em Materiais e Métodos. A porcentagem de células que proliferaram é indicada no gráfico. Representação de 3 experimentos realizados. 


\subsection{Rendimento Final da Cultura e Viabilidade Celular}

Após caracterização das células dendríticas, nosso segundo passo foi verificar se o aumento da temperatura modificaria o rendimento final da cultura ou a viabilidade dessas células.

A verificação do rendimento da cultura foi realizada através da contagem de células viáveis ao final da cultura em relação ao número inicial de células, conforme descrito em Materiais e Métodos. A figura 3 demonstra que as diferentes condições de cultura não afetaram o rendimento final da cultura, avaliado através de análise com Azul de Trypan.

Para confirmar que as células dendríticas não estavam em processo de morte células, que porventura não fosse detectado através de análise por Azul de Trypan, também verificamos se as diferentes condições de cultura poderiam induzir fragmentação de DNA, medida por incorporação de iodeto de propídeo. Conforme apresentado na figura 4, não houve diferença na taxa de morte celular entre as condições de cultura estudadas. 


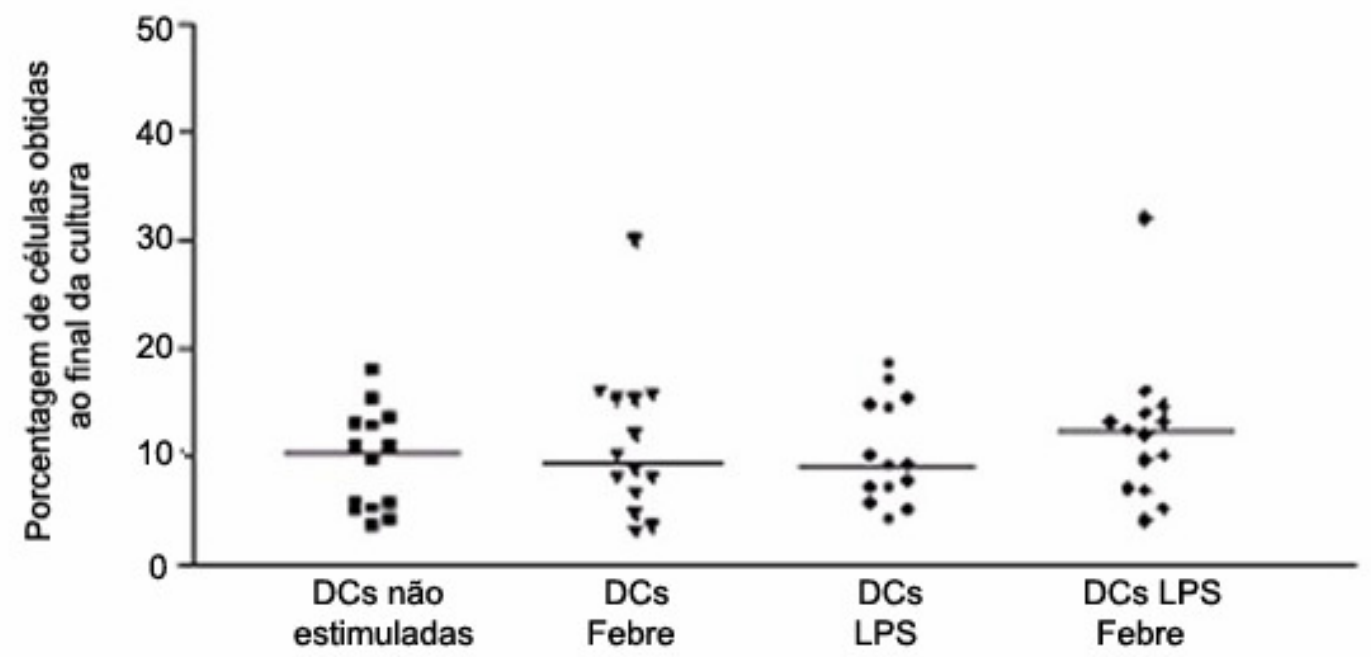

Figura 3: Rendimento Final da Cultura de DCs. Células mononucleares foram cultivadas em presença de GM-CSF e IL-4 e submetidas às diferentes condições de cultura. Ao final da cultura, a rendimento celular foi calculado, conforme descrito em Materiais e Métodos. Para análise estatística, foi realizado teste ANOVA para análises repetidas, seguido de teste de Comparações Múltiplas de Tukey $(p>0,05)$. Barra indica média. 

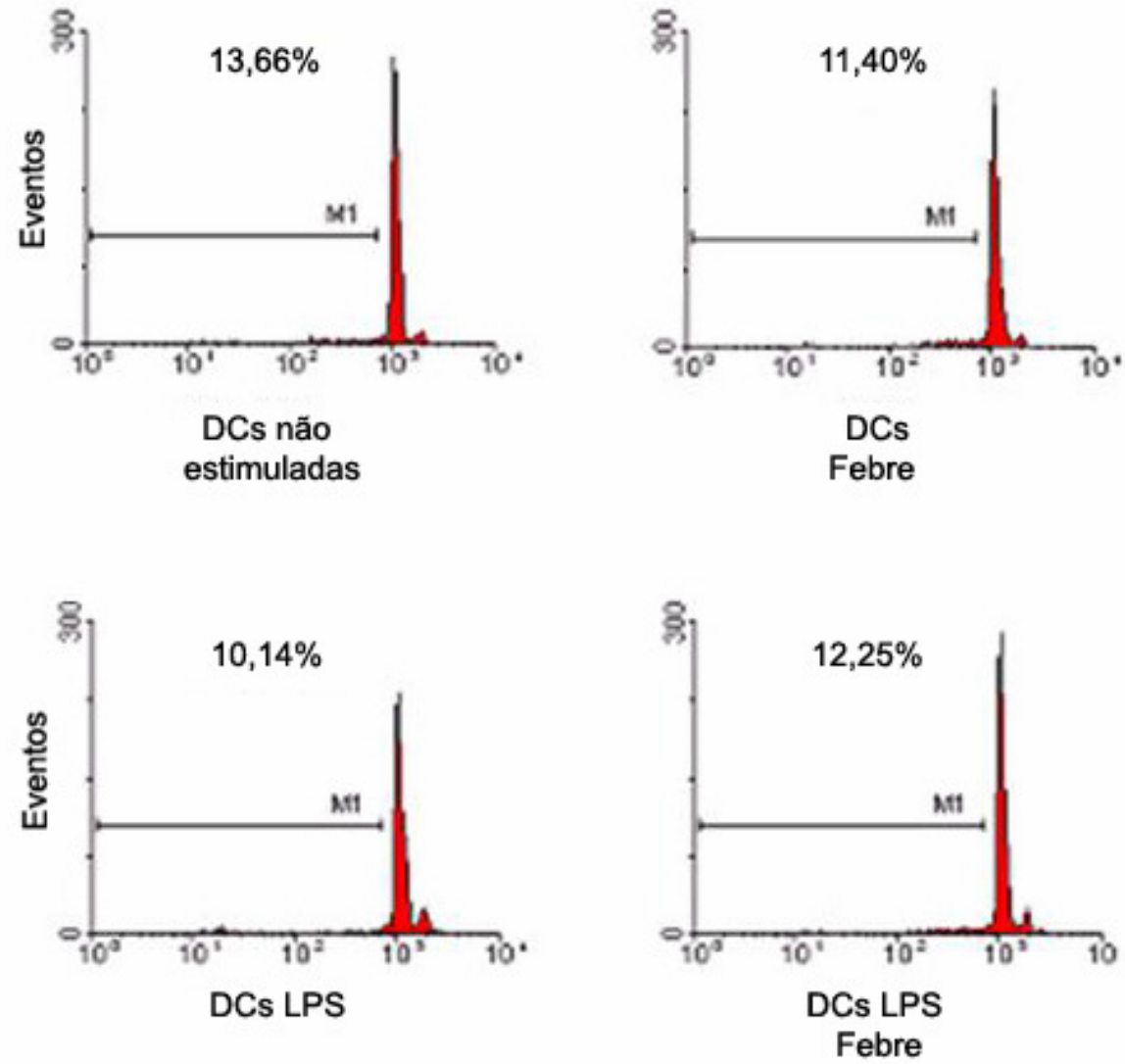

Figura 4: Viabilidade celular analisada por incorporação de iodeto de propídeo. Células mononucleares foram cultivadas em presença de GM-CSF e IL-4 e submetidas às diferentes condições de cultura. Ao final da cultura, as células foram incubadas com iodeto de propídeo em tampão hipotônico e analisadas por citometria de fluxo. A porcentagem de núcleo hipodiplóide é indicada na figura. A figura é representativa de 10 experimentos realizados. 


\subsection{Efeito da temperatura sobre a expressão de moléculas coestimuladoras na superfície de células dendríticas}

Após a caracterização da população a ser estudada e da confirmação de que as condições de cultura não afetam a viabilidade celular, investigamos em seguida se a temperatura febril afeta a ativação/maturação das DCs. A ativação ou maturação de células dendríticas pode ser caracterizada, entre outros fatores, pelo aumento da expressão de CD80, CD86 e CD40. Diante disso, nosso objetivo foi avaliar a expressão dessas moléculas na população de células em nossa cultura, caracterizadas como células CD14 CD11 ${ }^{+} H L A-D R^{+}$. A figura 5 demonstra que o estímulo sozinho com temperatura modificou significativamente a expressão da molécula co-estimuladora $\operatorname{CD40}(p<0,05)$, mas não houve diferença na porcentagem de células expressando a molécula (Figura 5). O estímulo com temperatura febril isolado não induziu alteração nas outras duas moléculas analisadas.

A estimulação com LPS induziu um aumento na intensidade de fluorescência de todas as moléculas, conforme esperado (Figura 6). No entanto, a temperatura febril não modificou significativamente a expressão de nenhuma das moléculas coestimuladoras em células estimuladas com LPS, em comparação quando com seu controle (Figura 6). A figura 7 é uma figura representativa dos experimentos realizados. 

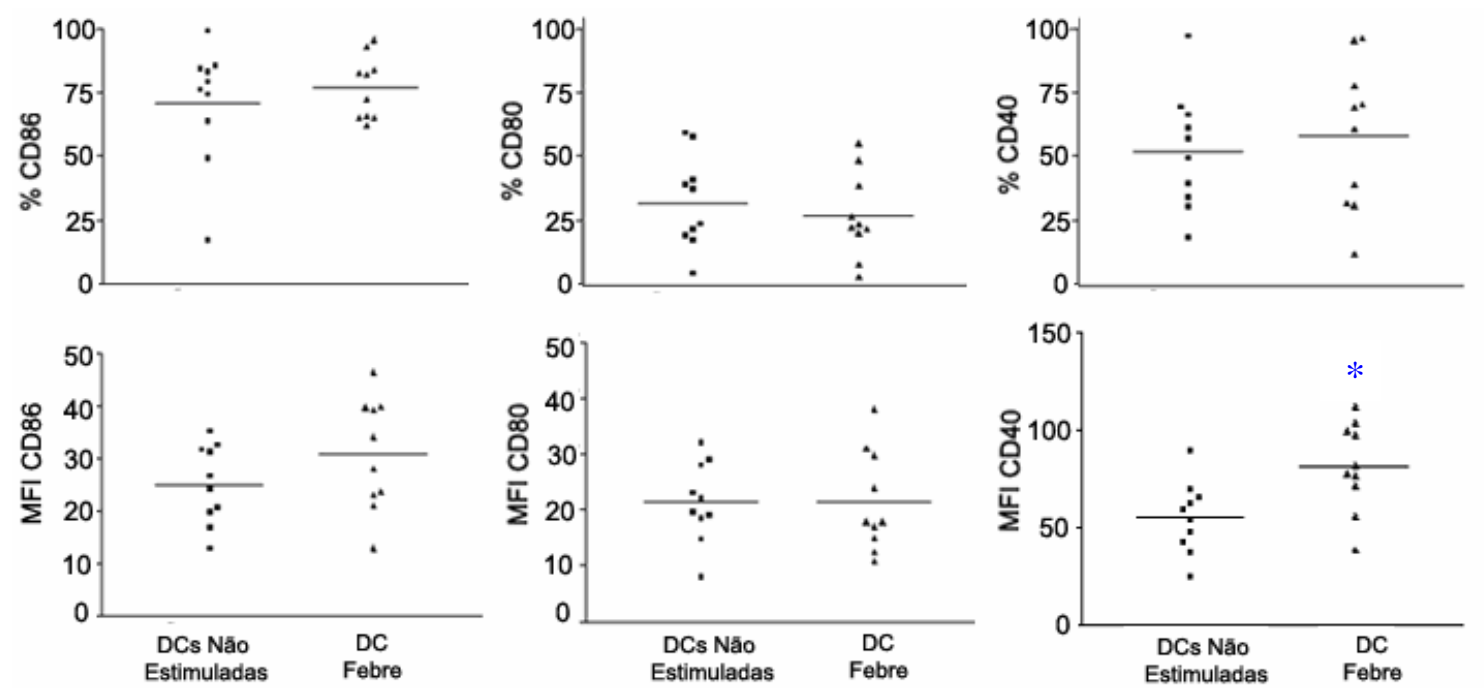

Figura 5: Análise da expressão de moléculas coestimuladoras na superfície de células dendríticas estimuladas somente com temperatura febril. Células mononucleares foram cultivadas em presença de GM-CSF e IL-4 e no $5^{\circ}$ dia foram transferidas à estufa $39^{\circ} \mathrm{C}$ (DCs Febre) ou permaneceram em estufa à $37^{\circ} \mathrm{C}$ (DCs não estimuladas). No $7^{\circ}$ dia, as células foram retiradas e marcadas com anticorpos anti-HLA-DR e CD11C para definição da população, juntamente com anti-CD80, anti-CD86 ou anti-CD40 e analisadas em citômetro de fluxo para avaliação da porcentagem de células expressando a molécula (\%) e intensidade de fluorescência média da molécula (MFI). A análise da porcentagem e MFI foi feita apenas na população $H L A-D R^{+} C D 11 c^{+}$, através do software CellQuest (Beckton \& Dickson). Para análise estatística foi realizado Teste t pareado de DCs Febre x DCs não estimuladas. Para CD86 e CD80, p > 0,05 na porcentagem de células expressando a molécula e MFI. Para CD40, $p$ $>0,05$ na porcentagem de células expressando a molécula e $p<0,05$ para MFI. Barra representa média de 10 experimentos realizados. Asterisco indica diferença estatisticamente significativa. 

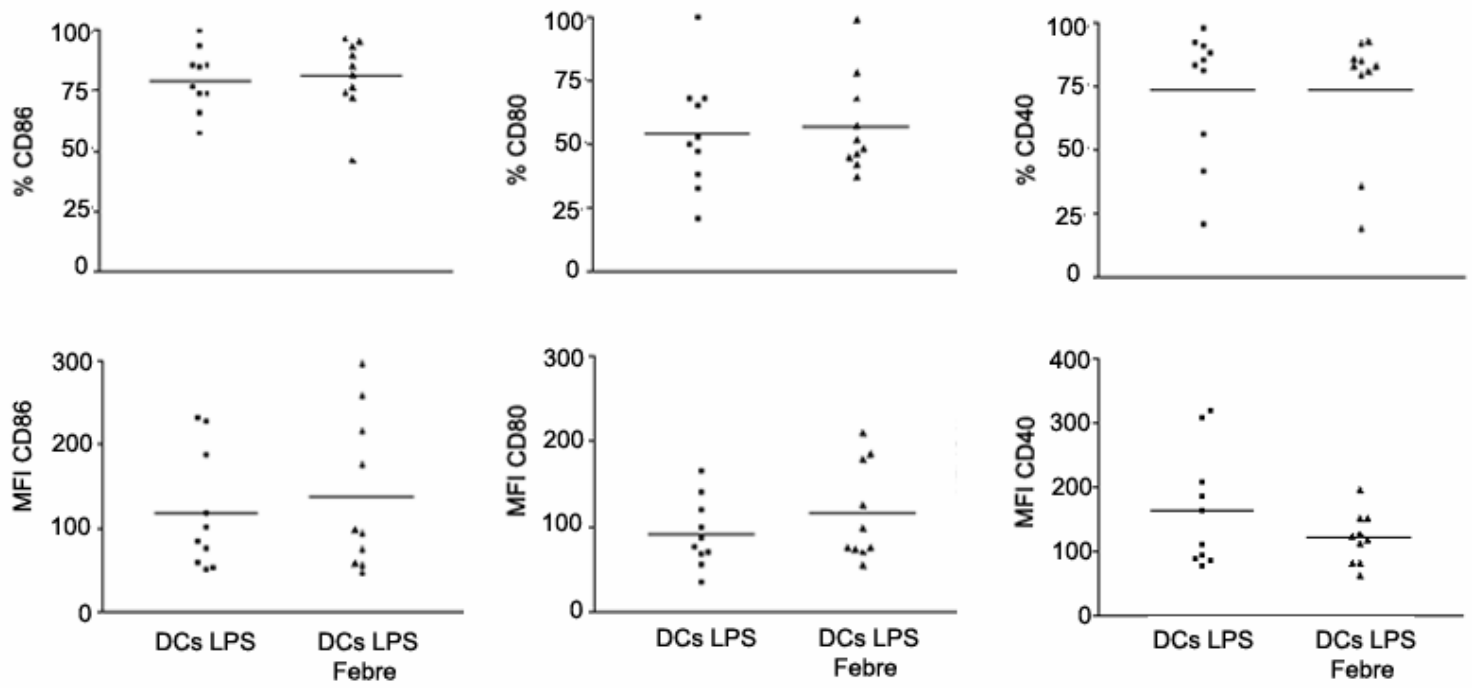

Figura 6: Análise da expressão de moléculas coestimuladoras na superfície de células dendríticas co-estimuladas com LPS e temperatura febril. Células mononucleares foram cultivadas em presença de GM-CSF e IL-4 e no $5^{\circ}$ dia foram transferidas à estufa $39{ }^{\circ} \mathrm{C}$ (DCs LPS Febre) ou permaneceram em estufa à $37^{\circ} \mathrm{C}$ (DCs LPS). No 6ํㅡㄹ dia, as células foram estimuladas overnight com LPS. e incubadas com anticorpos anti-HLA-DR e CD11C para definição da população, juntamente com anti-CD80, anti-CD86 ou anti-CD40 e analisadas em citômetro de fluxo para avaliação da porcentagem de células expressando a molécula (\%) e intensidade de fluorescência média da molécula (MFI). A análise da porcentagem e MFI foi feita apenas na população $\mathrm{HLA}-\mathrm{DR}^{+} \mathrm{CD} 11 \mathrm{c}^{+}$, através do software CellQuest (Beckton \& Dickson). Para análise estatística foi realizado Teste t pareado de DCs LPS $x$ DCs LPS Febre. Todas as moléculas analisadas apresentaram $p>0,05$ na análise estatística contra seu controle. Barra representa média de 10 experimentos realizados. 


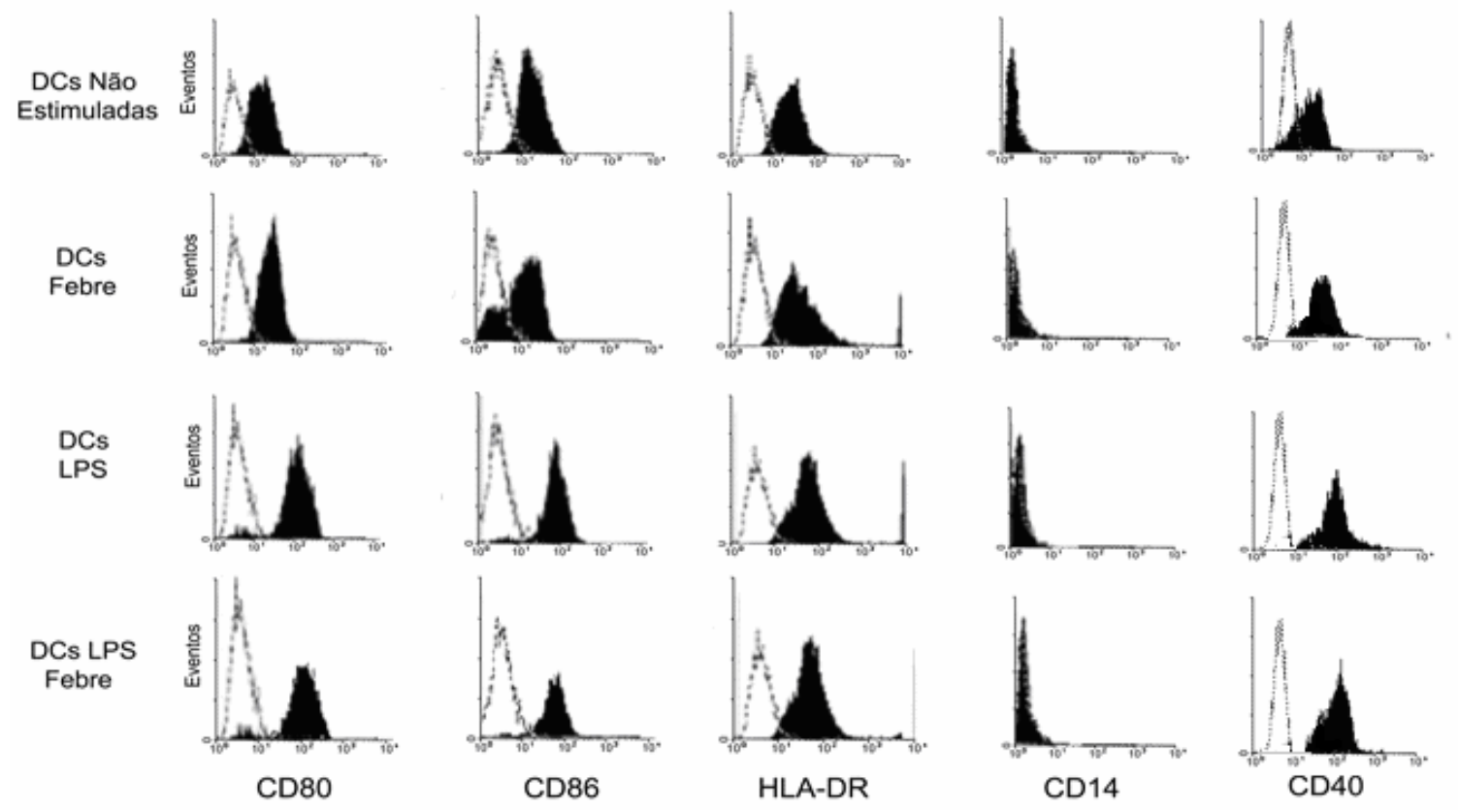

Figura 7: Análise da expressão de moléculas coestimuladoras na superfície de células dendríticas. Células mononucleares foram cultivadas em presença de GM-CSF e IL-4 e no $5^{\circ}$ dia foram submetidas às diferentes condições de cultura, conforme Materiais e Métodos. Após esse período, as células foram retiradas e marcadas com anticorpos anti-CD80, anti-CD86 e anti-CD40 e analisadas em citômetro de fluxo. A análise foi feita através do software CellQuest (Beckton \& Dickson). Figura é representativa de 10 experimentos realizados. 


\subsection{Efeito da temperatura sobre a capacidade endocítica de células dendríticas}

Um outro fator que caracteriza a ativação de DCs é a sua capacidade endocítica, uma vez que após a maturação, as células dendríticas diminuem a capacidade de capturar antígenos. Portanto, nós avaliamos a habilidade de DCs em endocitar conjugados Dextran-FITC após a estimulação com temperatura febril. Observamos que, novamente conforme esperado, o estímulo com LPS induz uma diminuição na habilidade de endocitose das DCs, mas no entanto, a temperatura febril não exerceu efeito sobre as DCs estimuladas ou não com LPS (Figura 8). Portanto, esses resultados sugerem que a febre não modifica a capacidade de DCs endocitar antígenos de forma eficiente. 

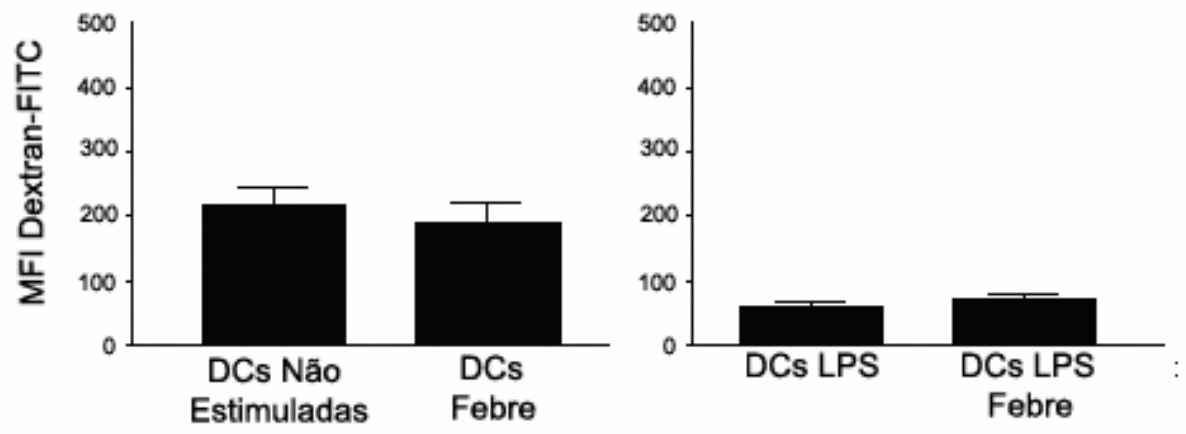

Figura 8: Capacidade endocítica das Células Dendríticas. Após cultura, células foram incubadas com Dextran-FITC e a incorporação do conjugado foi avaliada por citometria de fluxo. Valores no gráfico representam media da intensidade de fluorescência média (MFI) de 5 experimentos realizados. Barras indicam desvio padrão. Análise estatística através de teste T pareado mostrou que $p>$ 0,05 para os dois conjuntos de amostras analisados. 


\subsection{Secreção de TNF- $\alpha$, IL-10 e IL-12p70 por DCs cultivadas sob temperatura febril}

Além das moléculas coestimuladoras e da habilidade de endocitose, a ativação e função de DCs podem ser avaliadas através da produção de citocinas. Portanto, nós decidimos investigar se a temperatura febril poderia exercer algum efeito sobre a produção de citocinas que são expressas por DCs após sua ativação. Dentre as diversas citocinas produzidas por essas células, nós investigamos a produção de IL-12p70, que é uma importante citocina envolvida na modulação do perfil Th1 de linfócitos estimulados por DCs; IL-10 que é uma citocina responsável pelo controle e diminuição da resposta imune; e TNF- $\alpha$, que é uma citocina pró-inflamatória expressa por DCs e que participa da ativação de outras células. A figura 9 mostra que, embora tenha havido um aumento da produção de citocinas quando as células foram estimuladas com LPS, o nível de produção de citocinas não foi alterado na presença da temperatura febril. 

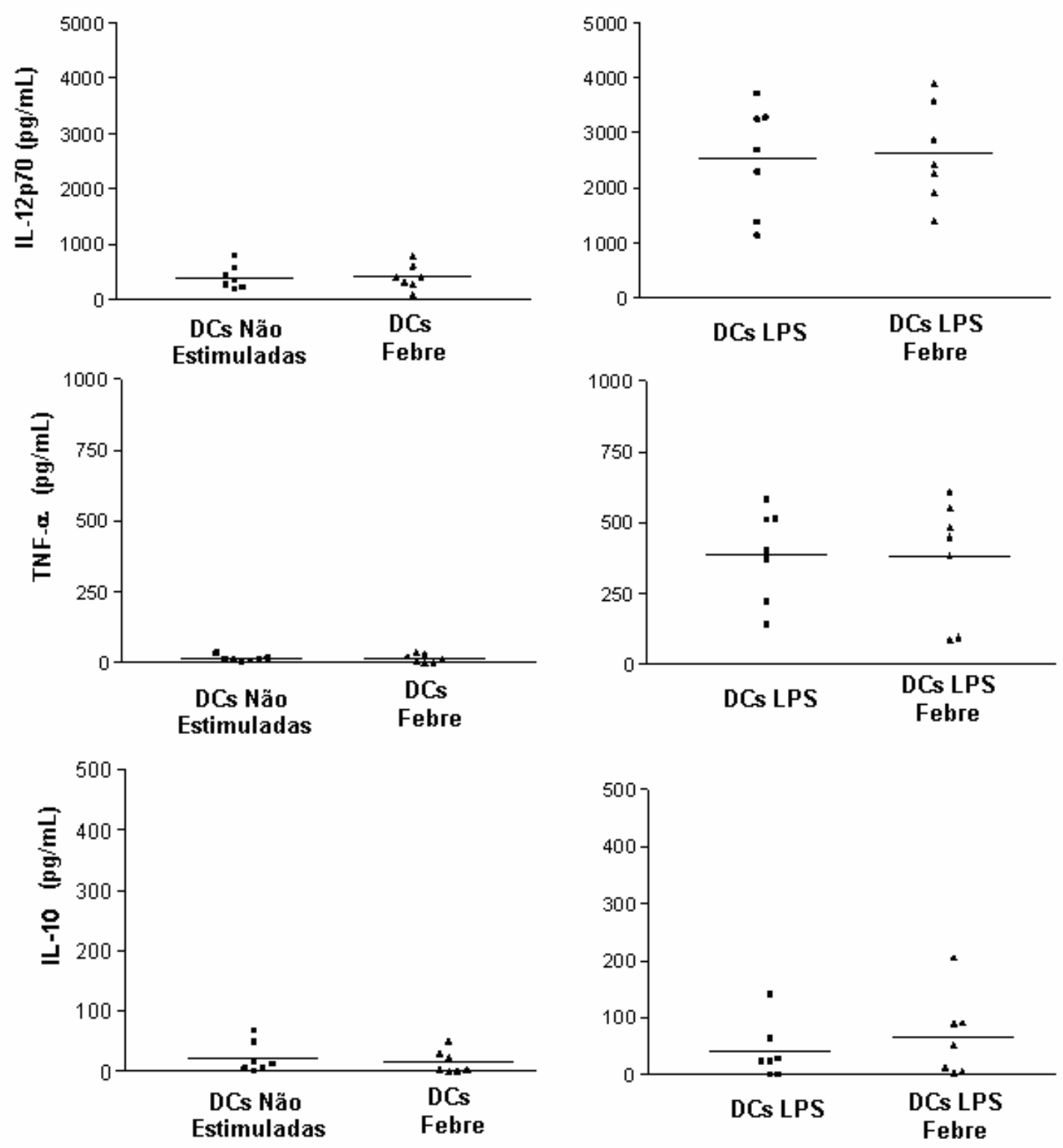

Figura 9: Avaliação de Produção de Citocinas por DCs ao Final da Cultura. Células mononucleares foram cultivadas em presença de GM-CSF e IL-4 e no $5^{\circ}$ dia foram submetidas às diferentes condições de cultura, conforme Materiais e Métodos Após a cultura a produção de IL-12p70, TNF- $\alpha$ and IL-10 em sobrenadante de cultura de DCs foi avaliada por ELISA. Para análise estatística foi realizado teste T pareado de DCs LPS x DCs LPS Febre ou DCs não estimuladas $x$ DCs Febre. Todas as moléculas analisadas apresentaram $p>$ 0,05 na análise estatística contra seu controle e considerou-se que não houve alteração estatisticamente significativa. Barra representa média de 7 experimentos realizados. 


\subsection{Efeito da temperatura febril sobre a atividade aloestimuladora de células dendríticas}

Nosso próximo passo foi verificar a atividade funcional de DCs através de seu potencial em ativar linfócitos T alogenêicos. CFSE é um corante fluorescente citoplasmático estável que segrega igualmente entre as células filhas após a divisão celular, possibilitando a análise da proliferação de linfócitos $\mathrm{T}$ in vitro. Observamos que embora não detectamos um aumento na produção de citocinas pelas DCs Febre ao final da cultura de diferenciação, essas células foram capazes de induzir um aumento na proliferação de células $T$ alogenêicas em comparação com as DCs não estimuladas (Figura 10). Por outro lado, quando as DCs foram estimuladas com LPS e temperatura febril, o estímulo com calor não foi capaz de aumentar a capacidade de estimulação das células dendríticas, com relação à estimulação já induzida com LPS isolado (Figura 10).

Surpreendentemente, entretanto, quando analisamos as sub-populações em proliferação observamos que, enquanto as DCs LPS induziram uma proliferação preferencialmente de linfócitos $\mathrm{T} \mathrm{CD} 4^{+}$, o estímulo com a temperatura febril modificou esse padrão, causando um aumento significativo na proporção de linfócitos T CD8 ${ }^{+}$em proliferação, representado pela razão CD4/CD8 (Figura 10). Entretanto, com relação às DCs não estimuladas com LPS, o estímulo com a temperatura não modificou o padrão de sub-populações em proliferação (Figura 11). 

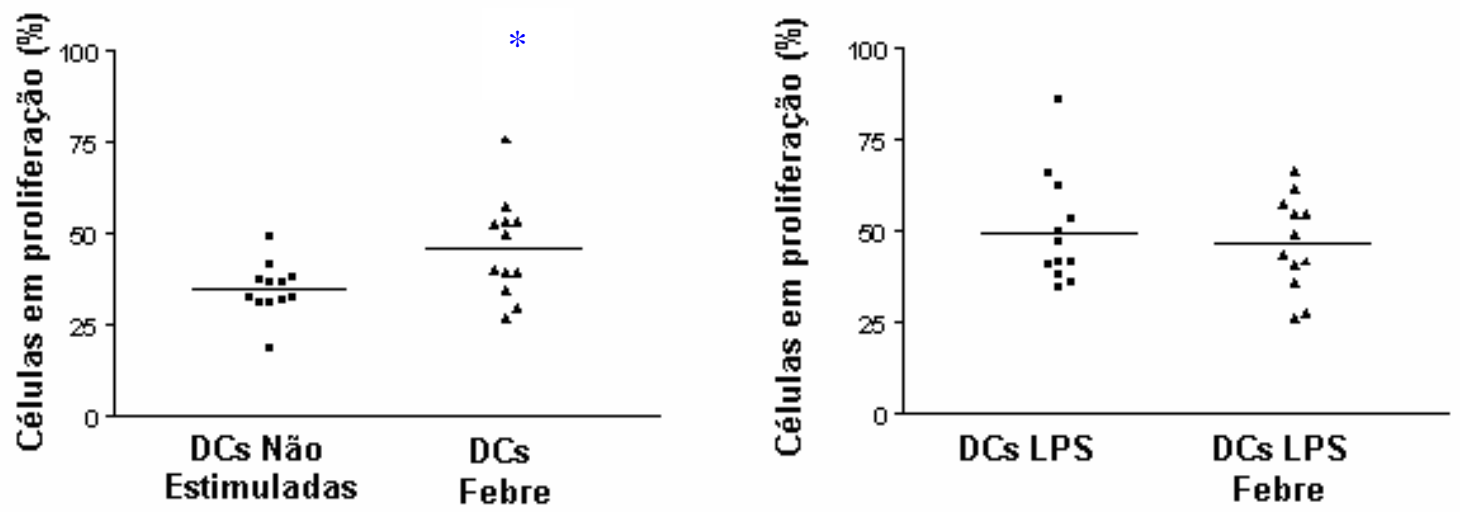

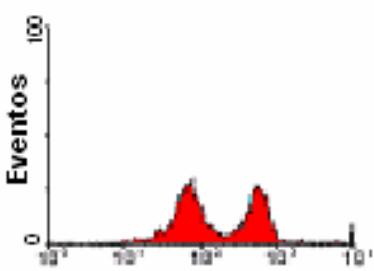

DCs Não

Estimuladas

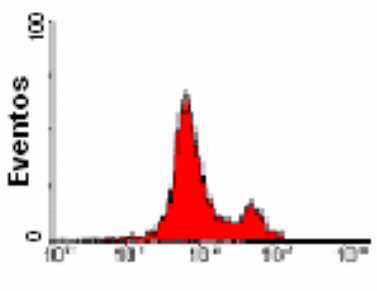

DCs LPS

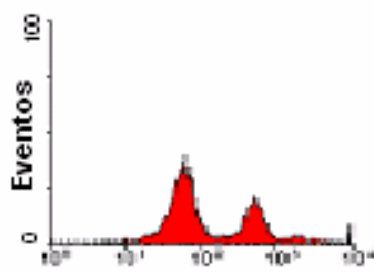

DCs

Febre

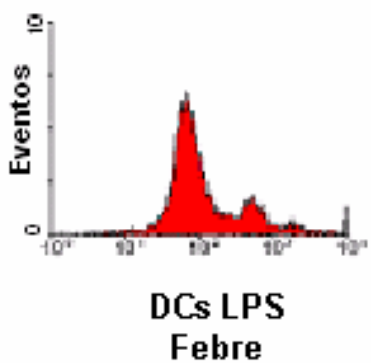

Figura 10: Atividade aloestimuladora de células dendríticas: A: Células obtidas de cocultura de células dendríticas irradiadas e linfócitos $T$ alogenêicos previamente incubados com CFSE foram analisadas em citometria de fluxo para avaliar a intensidade de fluorescência de CFSE após co-cultura, conforme descrito em Materiais e Métodos. Análise estatística através de teste $T$ mostrou: Diferença estatisticamente significativa de DCs não estimuladas $x$ DCs Febre $(p=0,0023)$; não houve diferença entre DCs LPS e DCs LPS Febre $(p>0,05)$. Barra representa média de 12 experimentos realizados. B: Histogramas representativos de 12 experimentos realizados. Asterisco indica diferença estatisticamente significativa. 

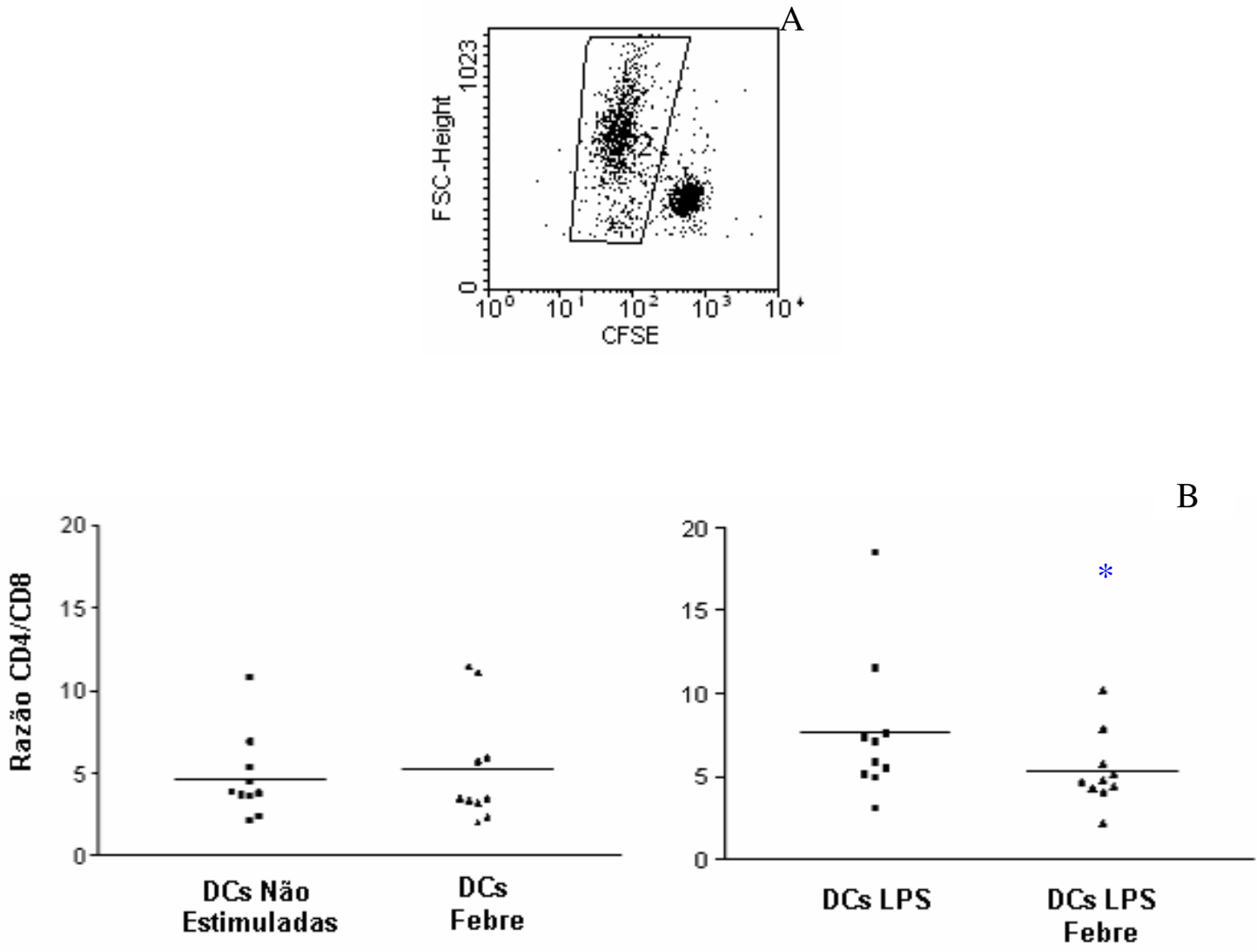

Figura 11: Sub-populações de linfócitos $T$ alogenêicos estimuladas por DCs. A: Células obtidas de co-cultura de células dendríticas irradiadas e linfócitos $T$ alogenêicos previamente incubados com CFSE foram analisadas em citometria de fluxo para avaliar a intensidade de fluorescência de CFSE após co-cultura, conforme descrito em Materiais e Métodos. Proliferação foi calculada por porcentagem de células que apresentaram diminuição na MFI de CFSE. A razão CD4/CD8 foi calculada dividindo-se a porcentagem de células CD4 em proliferação, pela porcentagem de células CD8 em proliferação. Maiores detalhes especificados em Materiais e Métodos. A análise foi realizada dentro da área delimitada na figura $A$, considerada como células que proliferaram. B: Análise estatística através de teste $T$ mostrou: diferença estatisticamente significativa de DCs LPS e DC LPS Febre $(p=$ 0,0118 ); não houve diferença entre DCs Não Estimuladas e DCs Febre ( $p>$ $0,05)$. Barra representa média de 10 experimentos realizados. Asterisco indica diferença estatisticamente significativa. 


\subsection{Efeito da Temperatura Febril sobre a Produção de Citocinas em Co- culturas Alogenêicas}

A análise da produção de citocinas nas co-culturas de DCs e linfócitos $T$ alogenêicos mostrou que culturas onde o estímulo com temperatura febril foi adicionado ao LPS para a ativação das DCs, um aumento na produção de IFN- $\gamma$ foi detectado nas co-culturas com linfócitos $T$ alogenêicos, em comparação ao detectado em co-culturas estimuladas por DCs ativadas somente com LPS (Figura 12). Esse aumento de produção de IFN- $\gamma$ não foi observado quando DCs Febre foram usadas como estimuladoras (Figura 13). A produção de IL-4 foi detectada somente em algumas co-culturas e somente quando as células estimuladoras foram DCs estimuladas com LPS. Quando existente, essa produção foi anulada frente ao estímulo com o calor em conjunto com LPS (Figura 13). As produções de IL-10, IL-12p70 ou TNF- $\alpha$ nas co-culturas não foram afetadas pela variação do estímulo de DCs. 

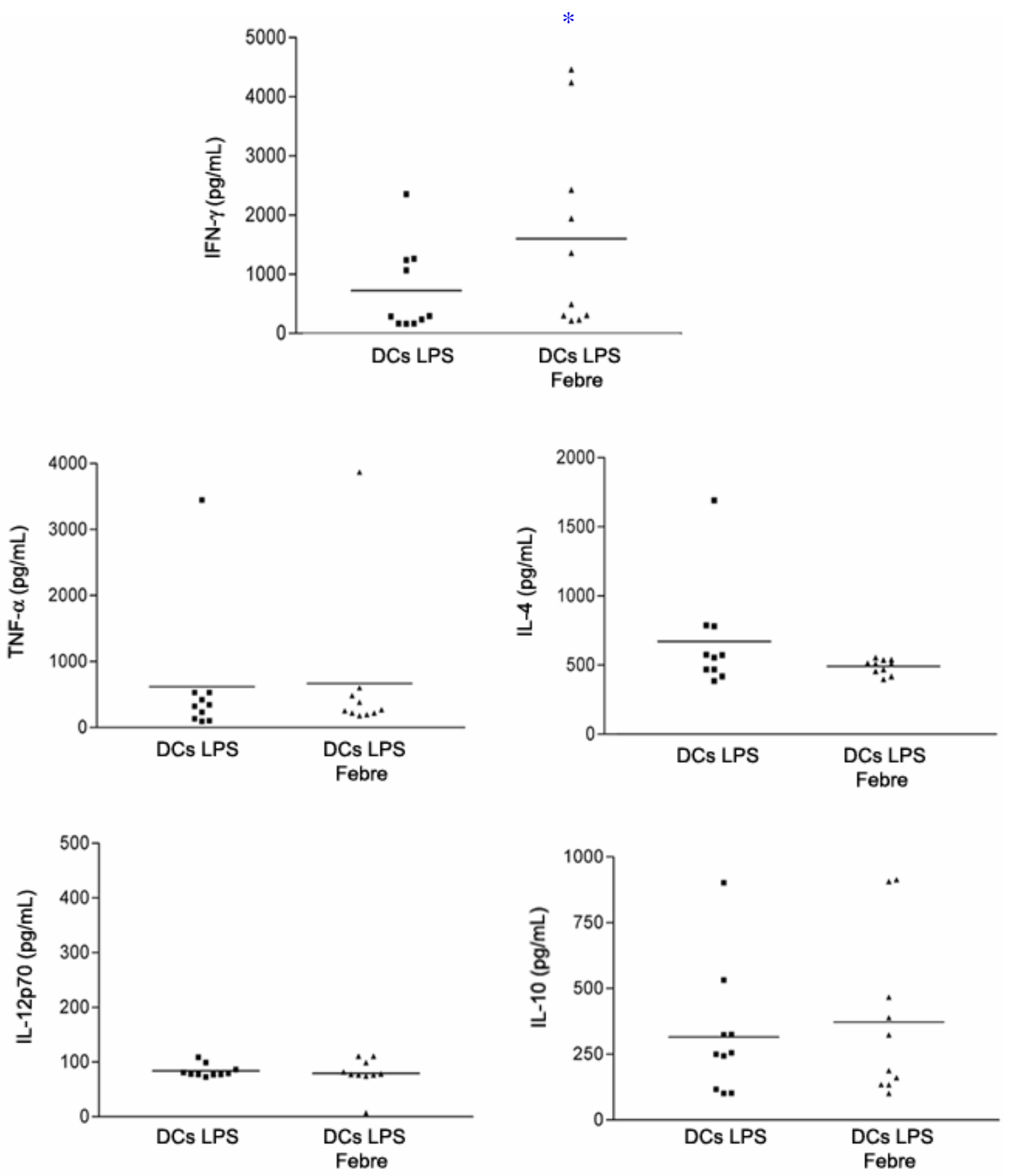

Figura 12: Produção de citocinas em co-culturas alogenêicas de células dendríticas submeticas às diferentes condições de cultura e linfócitos $T$ alogenêicos. Após a co-cultura, sobrenadantes foram coletados e a produção de citocina foi avaliada por ELISA. A figura mostra a produção em co-culturas alogenêicas com DCs não estimuladas e DCs estimuladas com temperatura febril, conforme descrito em Materiais e Métodos. Para análise estatística foi usado teste T pareado que mostrou: produção de IFN- $\gamma$ ( $p=$ $0,0253)$. Para todos as outras citocinas: $p>0,05$. Barra representa média de 10 experimentos realizados. Asterisco indica diferença estatisticamente significativa. 

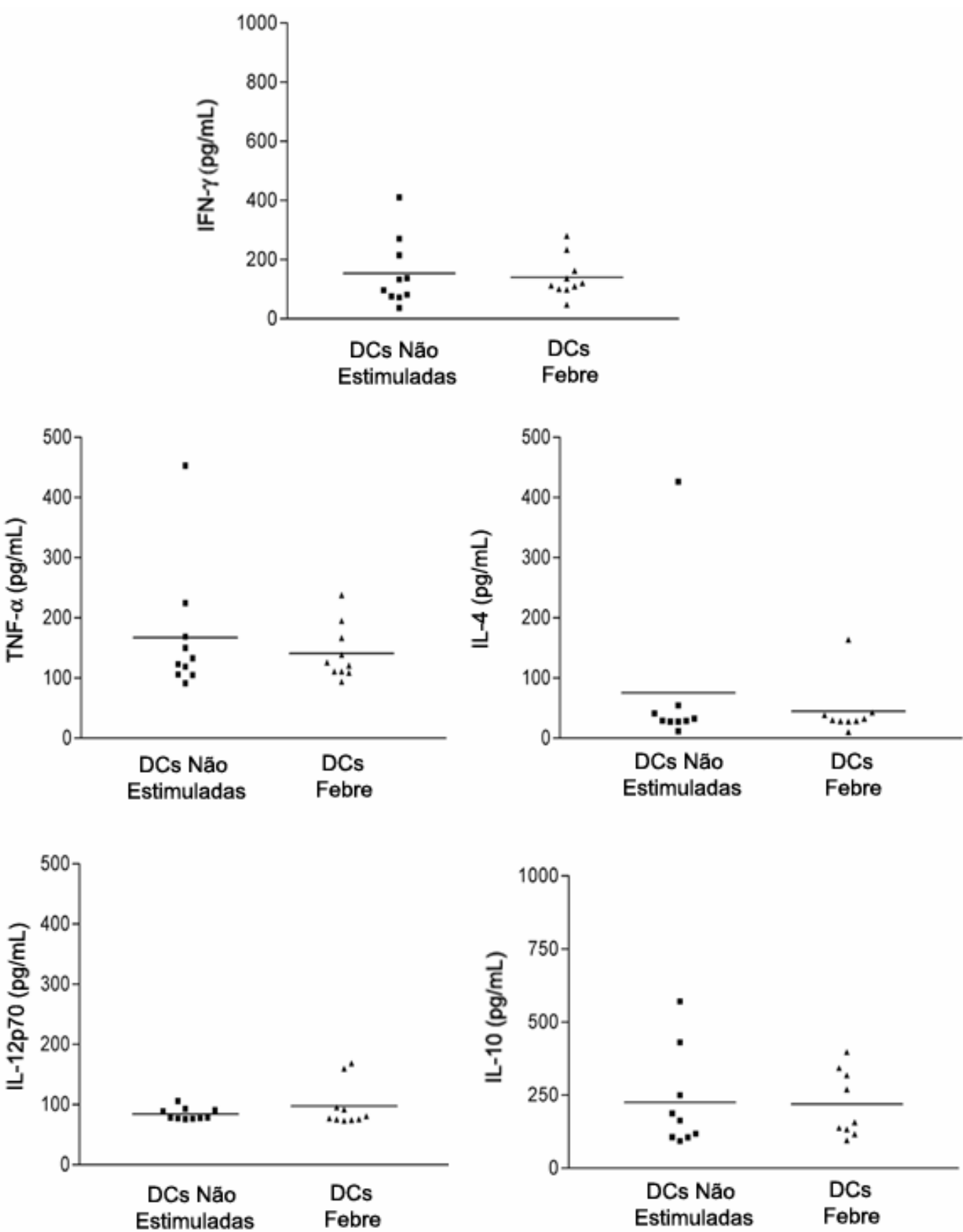

Figura 13: Produção de citocinas em co-culturas alogenêicas de células dendríticas submetidas às diferentes condições de cultura e linfócitos $T$ alogenêicos. Após a co-cultura, sobrenadantes foram coletados e a produção de citocina foi avaliada por ELISA. A figura mostra a produção em co-culturas alogenêicas com DCs não estimuladas e DCs estimuladas com temperatura febril, conforme descrito em Materiais e Métodos. Para análise estatística foi usado teste $T$ pareado que mostrou: $p>0,05$ para todas as citocinas analisadas. Barra representa média de 10 experimentos realizados. 


\subsection{Análise da Expressão de Heat Shock Protein (HSP) - 70 na Superfície} Celular de Células Dendríticas

A expressão de HSPs é aumentada como parte da resposta a diversos tipos de estresse. Diante disso, avaliamos se a expressão de HSP70 poderia estar aumentada na membrana de células dendríticas ao final da cultura. Observamos que, ao final de nossas culturas, não foi detectado HSP70 nas membranas dessas células, de maneira diferente das células controle (Figura 14). Portanto, as HSP70 localizadas na membrana possivelmente não estão envolvidas no aumento da atividade estimuladora das DCs observada com o aumento da temperatura. 

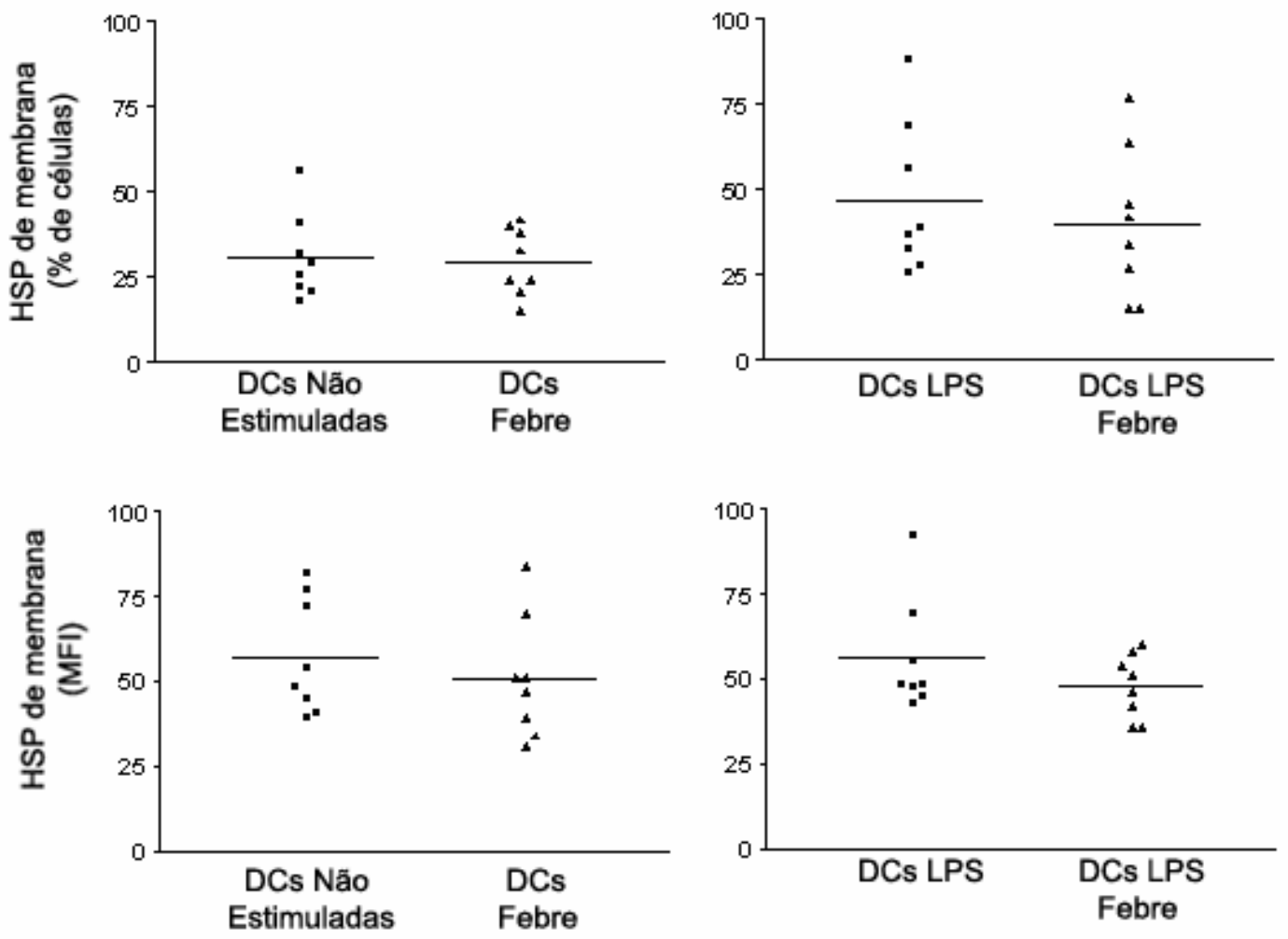

Figura 14: Análise da expressão HSP70 na superfície de células dendríticas. Células mononucleares foram cultivadas em presença de GM-CSF e IL-4 e no $5^{\circ}$ dia foram submetidas às diferentes condições de cultura, conforme Materiais e Métodos. Após esse período, as células foram retiradas e marcadas com anticorpos anti- HLA-DR e CD11c, juntamente com anti-HSP70 e analisadas em citômetro de fluxo. A análise da porcentagem e MFI foi feita apenas na população $\mathrm{HLA}-\mathrm{DR}^{+} \mathrm{CD} 11 \mathrm{c}^{+}$, através do software CellQuest (Beckton \& Dickson). 


\section{DISCUSSÃO}

O presente estudo teve como objetivo investigar os efeitos da temperatura febril $\left(39,5^{\circ} \mathrm{C}\right)$ na ativação e fenótipo de DCs, através da análise de expressão de moléculas coestimuladoras, capacidade de internalização de antígenos e produção de citocinas, assim como na resposta de linfócitos $T$ induzida por estas células. Além de analisarmos os efeitos da febre isoladamente, também verificamos a modificação da resposta na presença de LPS, um PAMP (padrão molecular associado a patógeno) com conhecida capacidade de ativação de células dendríticas (TAKEDA; KAISHO; AKIRA, 2003; FLACHER et al., 2006). Os resultados encontrados sugerem que a febre pode modular a expressão de moléculas coestimuladoras por células dendríticas, assim como modificar a resposta alogenêica induzida pelas DCs.

Antes de iniciar a análise dos efeitos da temperatura febril sobre as células dendríticas (DCs), nosso primeiro passo foi verificar as características fenotípicas das células geradas em nossas culturas. Os resultados encontrados demonstraram que as células geradas apresentavam as características fenotípicas de células dendríticas, conforme descrito na literatura (ROMANI et al., 1996; ZHOU e TEDDER, 1996; VERHASSELT et al., 1997), avaliadas através da análise de expressão de CD11c, HLA-DR, CD86 e CD40, e ausência de expressão do marcador de monócitos CD14. Interessantemente, as células dendríticas geradas em nossos estudos também apresentaram expressão de CD80 mesmo sem estímulo para ativação. De acordo com alguns relatos da literatura, a expressão da molécula CD80 em DCs só ocorre após estimulação (FREEDMAN et al., 1991; HATHCOCK et al., 1994; SLAVIK et al., 1999), o que estaria em aparente contradição com nossos dados. No entanto, diversos trabalhos realizados com células humanas geradas através de cultura in vitro apresentam a expressão de moléculas coestimuladoras, mesmo na ausência de ativação (BROSSAR e BRUGGER, 2000; PENG et al., 2006). Uma das hipóteses que poderiam explicar a expressão precoce da molécula CD80 em nossos experimentos pode ser a 
metodologia das condições de obtenção de células dendríticas. Larsen et al. (1994), descrevem que a citocina GM-CSF induziu um aumento da expressão das moléculas CD80 e CD86 em DCs esplênicas murinas cultivadas e essa citocina também foi utilizada como fator de diferenciação em nossas culturas. A expressão precoce de CD80 também foi observada em estudos anteriores realizados em nosso laboratório, que demonstraram um aumento da expressão das moléculas coestimuladoras CD80 e CD86 em resposta ao aumento da concentração das citocinas IL-4 e GM-CSF na cultura (NEVES et al., 2003).

Além disso, os monócitos precursores utilizados em nossas culturas foram obtidos através de um processo de leucoferese, o qual pode ter contribuído para uma expressão precoce, embora de baixa magnitude, de moléculas coestimuladoras. É possível que um estresse inicial provocado pelo processo de leucoferese, adicionado à presença de citocinas no meio de cultura, possa ter contribuído para uma sinalização de expressão nas células geradas. A hipótese da expressão de moléculas coestimuladoras como resultado de um estresse associado a condições de culturas pode ser bastante razoável, quando consideramos que as células dendríticas, por sua natureza e função, devem estar sensíveis a qualquer alteração ambiental, visto que são elas as "sentinelas" do sistema imune (SHORTMAN e LIU, 2002). No entanto, a expressão das moléculas coestimuladoras observada nas DCs não estimuladas era muito baixa e teve um aumento marcante após estímulo com LPS, sugerindo que as DCs ainda não apresentavam um fenótipo de ativação antes da adição do estímulo, apesar da expressão precoce de CD80.

O efeito da temperatura febril pode ser analisado sob diversas condições de cultura ou condições experimentais. Grupos de trabalho que estudaram o efeito da temperatura sobre as DCs utilizaram períodos diferentes de estimulação, que variaram de 2 horas a 24 horas (OSTBERG; PATEL; REPASKY, 2000; OSTBERG et al., 2000, 2001; OSTBERG; KABINGU; REPASKY, 2003; TOURNIER et al., 2003; YAN et al., 2006). Com o intuito de determinar um delineamento a ser utilizado em nossos estudos, experimentos preliminares foram realizados 
considerando diferentes períodos de exposição à temperatura febril, e o parâmetro escolhido para análise nesses experimentos preliminares foi a capacidade de estimulação alogenêica das DCs, uma vez que entendemos que este parâmetro indica a atividade das células dendríticas. Como se tratava de uma análise preliminar, apenas três experimentos foram realizados para a determinação do delineamento das condições de cultura. Observamos que a temperatura febril $\left(39,5^{\circ}\right.$ C) era capaz de induzir um aumento da atividade aloestimuladora de DCs sobre linfócitos alogenêicos em todas as condições de cultura testadas. Além disso, também encontramos que os resultados apresentavam uma grande variabilidade, embora não excluíssem um efeito da febre sobre a atividade estimuladora das DCs. Contudo, esse aumento na atividade aloestimuladora das DCs geradas de monócitos humanos foi observado de maneira consistente, ou seja, em todos os indivíduos analisados, quando as células foram estimuladas por 48 horas sob temperatura febril. Diante disso, esse período de estimulação foi escolhido para a continuidade de nossos estudos.

Após a definição do delineamento experimental, avaliamos se o período de estimulação escolhido poderia induzir algum efeito sobre a viabilidade celular ou rendimento final da cultura, até mesmo pela extensão de exposição a uma alta temperatura. Além disso, a primeira hipótese a ser considerada é de que as observações encontradas em nossos experimentos preliminares, que indicaram um aumento da atividade aloestimuladora por DCs estimuladas por temperatura febril, poderiam ser em decorrência da presença de sinais de perigo liberados por células mortas na vizinhança. É descrito na literatura que células necróticas e células apoptóticas estressadas pelo calor são capazes de liberar proteínas de choque térmico, como por exemplo as gp96, HSP70 e HSP90, as quais podem ser consideradas "sinais de perigo" (BASU et al., 2000; MOSELEY, 2000; TODRYK et al, 2000). Nossos dados indicam que não houve redução do rendimento da cultura sob as diferentes condições, assim como também não foi observada morte celular por Azul de Trypan ou fragmentação de DNA por citometria de fluxo. Desta forma, observou-se que a temperatura e o período de estimulação utilizados não influenciaram a viabilidade das células da cultura. 
Um outro parâmetro sobre o qual a temperatura poderia atuar é a capacidade de internalização de antígenos pelas DCs. É conhecido que a função primordial de DCs imaturas é a captura de antígenos no momento inicial de exposição e, após a ativação, a perda da capacidade de internalização para iniciar a atividade de apresentação do antígenos para linfócitos T (OSTBERG e REPASKY, 2006). Nossos resultados demonstraram que após o estímulo com LPS as células apresentaram uma diminuição da atividade endocítica, o que está de acordo com os conhecimentos prévios sobre ativação de DCs e internalização de antígenos. No entanto, a adição do estímulo febril, em células ativadas ou não com LPS, não induziu qualquer efeito sobre a capacidade de internalização dos complexos.

A internalização de complexos Dextran-FITC pode ser modulada pela temperatura e estudos em outros tipos de APCs, como macrófagos peritoneais residentes, demonstraram que a elevação da temperatura em $40{ }^{\circ} \mathrm{C}$ induziu um aumento da fagocitose em aproximadamente 40\% (YOSHIOKA et al., 1990; VAN BRUGGEN; ROBERTSON; PAPADIMITRIOU, 1991; OSTBERG e REPASKY, 2006). No entanto, os resultados encontrados em nossos estudos não revelaram um efeito visível do aumento da temperatura sobre a capacidade de endocitose de complexos Dextran-FITC pelas DCs. A ausência de efeito da temperatura febril observada em nossos experimentos pode indicar que a variação na temperatura não tenha causado um efeito perceptível sobre a internalização de antígenos através de receptores para manose, quando consideramos o efeito de um sinal de perigo (LPS), o qual induz uma marcante redução da função de captura em DCs. Diante da ausência de indícios de que os efeitos térmicos observados em nossos experimentos preliminares estavam associados à internalização dos complexos, resolvemos avaliar se os resultados observados sobre a atividade estimuladora de DCs poderiam estar relacionados com outros fatores, como o aumento da capacidade de apresentação antigênica através da expressão de moléculas coestimuladoras. 
Dentre as diversas moléculas coestimuladoras que participam da indução de resposta por células dendríticas, foram escolhidas as moléculas CD40, CD80 e CD86, devido ao seu importante papel na ativação da resposta imune. As moléculas CD80 e CD86 são essenciais na ativação de linfócitos T, já que se ligam ao receptor CD28, permitindo a estimulação das células. A interação do CD28 com as moléculas CD80 ou CD86 expressas por células apresentadoras de antígeno fornece um forte sinal coestimulador aos linfócitos $\mathrm{T}$, resultando na indução de IL-2 e entrada no ciclo celular (CARRENO e COLLINS, 2002). Já a molécula CD40 exerce uma função vital na função de células dendríticas e tem sua expressão aumentada quando as DCs migram da periferia para os linfonodos drenantes, em resposta a um desafio microbiano (O'SULLIVAN e THOMAS, 2003). A ligação do CD40 com seu ligante CD154, expressos por linfócitos T ativados induz a diferenciação final de DCs, através do aumento das moléculas coestimuladoras e moléculas de adesão. Além disso, a ligação do CD40 nas DCs induz a produção de IL-12 por estas células, que por sua vez induz a diferenciação de linfócitos T CD4+ para um fenótipo Th1, aumentando a proliferação de células T CD8+. (O'SULLIVAN e THOMAS, 2003). Desta forma, a investigação dessas moléculas poderia nos trazer indícios sobre uma possível modulação da febre sobre a resposta induzida por DCs.

Observamos que a estimulação das DCs com LPS sozinho causou um aumento significativo das três moléculas coestimuladoras analisadas. Tal aumento na intensidade de expressão das moléculas coestimuladoras já era esperado, uma vez que o LPS é um conhecido "sinal de perigo" e forte estimulador de DCs (VERHASSELT et al., 1997; KAISHO et al., 2001). Diante disso, foi possível constatar que, com relação às moléculas coestimuladoras, as DCs geradas em nossa cultura apresentavam a resposta prevista frente ao controle positivo escolhido.

Por outro lado, quando analisamos o efeito do estímulo febril sozinho sobre a expressão das moléculas coestimuladoras em DCs, observamos que somente a molécula CD40 apresentou um aumento significativo com relação às células não 
estimuladas. No entanto, tal aumento, apesar de significativo, não foi da mesma magnitude do aumento observado com a estimulação por LPS, considerando a intensidade de fluorescência. Com relação às moléculas CD80 e CD86, não houve um aumento significativo em relação às DCs não estimuladas. Contudo, quando analisamos cuidadosamente os resultados, podemos observar que em alguns indivíduos ocorre certo aumento da intensidade de fluorescência do CD86, enquanto que em outros não há qualquer variação na expressão dessa molécula. Tal aumento observado em alguns indivíduos pode ser considerado de pequena magnitude, quando comparado ao aumento induzido pela presença de LPS, e não é possível afirmar se esta pequena variação na intensidade de fluorescência já seria suficiente para uma modificação da resposta. No entanto, é interessante compará-la à expressão da molécula CD80, que não variou em nenhum dos indivíduos analisados e apresentou uma expressão aparentemente uniforme. Já a molécula CD40 foi modulada em todos os indivíduos analisados, em maior ou menos proporção. Diante disso, podemos especular que o estímulo febril atuaria de maneira diversa entre as moléculas coestimuladoras, com participação mais evidente sobre a molécula CD40. Considerando que, diferentemente da expressão de CD86, que teve uma variação sutil em apenas alguns indivíduos e de CD80, que não variou, os resultados podem sugerir que a expressão de CD40 seria um dos mecanismos pelos quais a febre atuaria sobre as DCs.

Uma vez que a expressão de CD40 está relacionada com a ativação de DCs e indução de resposta proliferativa, resolvemos confirmar os resultados preliminares obtidos quanto a indução de resposta alogenêica por DCs estimuladas com temperatura febril, investigando um maior número de indivíduos. Observamos que, assim como esperado, tanto nosso controle positivo (LPS), como a temperatura febril induziu um aumento na atividade de estimulação alogenêica por DCs, quando analisado um maior número de indivíduos. No entanto, apesar de acompanhado pelo aumento da expressão de CD40, não foi observada uma elevação da produção de citocinas na cultura de diferenciação de DCs após o estímulo febril ou na co-cultura de tais DCs com linfócitos T. Uma possível explicação para os dados encontrados, é a ausência, neste sistema, de 
um fator associado à febre, isto é, um "sinal de perigo". Ou seja, apenas a temperatura febril não seria suficiente para gerar uma resposta completa. No entanto, embora o sistema estabelecido em nossos estudos, de um estímulo isolado com temperatura febril, não represente uma situação real, ele pode nos sugerir indícios de que o estímulo febril é capaz de atuar diretamente e participar da modulação da resposta imune nas células dendríticas, inclusive através do aumento da expressão de moléculas coestimuladoras.

Nossos dados com relação à expressão de moléculas coestimuladoras indicaram um aumento da expressão de CD40 com o estímulo febril, o qual foi acompanhado de um aumento da indução de proliferação de linfócitos por DCs. No entanto, para que a resposta gerada pelas células dendríticas fosse efetiva, haveria a necessidade de uma ativação mais completa, como a que ocorre através de TLRs. (TAKEDA e AKIRA, 2001; KAISHO e AKIRA, 2002; TAKEDA; KAISHO; AKIRA, 2003). Por exemplo, DCs podem expressar TLR4, que medeia 0 reconhecimento de LPS bacteriano e vários outros PAMPs (TAKEDA e AKIRA, 2001; TAKEDA; KAISHO; AKIRA, 2003). O reconhecimento de PAMPs por TLRs leva à ativação de fatores de transcrição NF-kB, assim como MAPKs (proteínas quinases ativadas por mitógenos), e consequentemente à regulação da expressão de citocinas e moléculas coestimuladoras nas células imune, controlando assim a ativação da resposta adaptativa (KAISHO e AKIRA, 2002; BARTON e MEDZHITOV, 2003).

Deste modo, conforme observado em nossos resultados, o estímulo com LPS é capaz de induzir o aumento da expressão de moléculas coestimuladoras, seguido de aumento da atividade aloestimuladora e produção de citocinas, já que sua interação ocorre através de TLRs. Já a resposta induzida pelo estímulo febril isolado, onde a proliferação alogenêica não foi acompanhada do aumento da produção de citocinas, poderia ser explicada pela ausência de ativação através de TLRs, o que geraria uma resposta incompleta. Dentro dessa linha de raciocínio, é interessante citar um estudo realizado por Yan et al. (2006), que avaliou o efeito da hipertermia frente ao estímulo com LPS, demonstrando que a temperatura 
febril $(39,5 \stackrel{\circ}{ } \mathrm{C})$ promoveu a expressão de TLR4 em DCs derivadas de medula óssea de camundongos, levando consequentemente ao aumento da produção das citocinas IL-6, IL-10 e IL-12. É possível que o estímulo febril seja um potencializador da resposta induzida por um "sinal de perigo", modulando a expressão de CD40 e de TLR4. No entanto, o fator crítico para a ativação da resposta imune seria a ligação do PAMP ao TLR, evitando assim uma indução de atividade imune inespecífica ou não desejada.

Portanto, os resultados observados mostraram que a temperatura febril isolada induz um aumento da expressão da molécula coestimuladora CD40, no entanto, tal aumento parece provocar uma resposta incompleta por DCs, já que a atividade aloestimuladora observada não foi acompanhada da produção das citocinas analisadas, ou seja, IFN-y, IL-4, IL-10 ou IL-12. Além disso, não podemos excluir 0 efeito da temperatura febril sobre outras moléculas coestimuladoras que não foram analisadas no presente trabalho, tais como OX40L, CD70, 4-1BB-L (LADERACH; WESA; GALY, 2003; TARABAN; ROWLEY; ALSHAMKHANS, 2004; SCHUURHUIS et al., 2006; SANCHEZ et al., 2007; JENKINS et al., 2007).

O aumento da expressão de CD40, acompanhado do aumento na indução de resposta alogenêica por DCs estimuladas com temperatura febril por 48 horas, encontrados em nossos estudos, estaria em aparente contradição quando comparados a outros trabalhos da literatura (TOURNIER et al., 2003; HATZFELDCHARBONNIER et al., 2007). De acordo com esses trabalhos, a temperatura febril por si só não é capaz de modificar ou induzir resposta na ausência de um estímulo microbiano (OSTBERT; KABINGU; REPASKY, 2003; PENG et al., 2006). A descrição de resultados contraditórios a respeito do papel da hipertermia também pode ser encontrada para outros tipos celulares, como nos trabalhos que demonstram que a elevação da temperatura pode aumentar (ZANKER e LANGE, 1982; HAJTO, 1985; DOWNING e TAYLOR, 1987; OSTBERG et al., 2000) ou pode inibir (IZUMI;KOGA;MAETA, 1983; SITNICKA; OLSZEWSKI; LUKOMSKA, 1993; SHEN et al., 1994;) a atividade citolítica de linfócitos T e células NK. Na 
análise dos resultados frente aos dados da literatura, devemos considerar as diferenças de condições de cultura entre os estudos, principalmente quando se trata de dados obtidos in vitro (OSTBERG et al., 2000). Nossos estudos foram realizados com um período de exposição febril superior aos períodos aplicados por outros autores, que variam de 2 horas a 24 horas (OSTBERG et al., 2000; OSTBERT; PATEL; REPASKY, 2000; OSTBERG et al., 2001; OSTBERG e REPASKY, 2006; TOURNIER et al., 2003; YAN et al., 2006). Poderíamos especular que apenas após um período extenso de exposição à temperatura febril, as DCs foram suficientemente estimuladas para a geração da resposta, reconhecendo a persistência de calor como um sinal. Tal explicação estaria de acordo com os nossos estudos preliminares, onde observamos que apenas após 48 horas obtivemos uma resposta proliferativa presente em todos os indivíduos analisados. Também estaria de acordo com os dados citados por Peng e colaboradores, que descrevem um aumento da resposta de DCs proporcional à extensão da hipertermia, avaliada desde 4 horas até 48 horas de exposição ao calor (PENG et al., 2006) e por dados levantados por Ostberg et al. (2005), demonstrando que a fonte de DCs e a duração do estímulo térmico pode ser importante na detecção dos efeitos do estresse pelo calor sobre a maturação de DCs.

Quando analisamos os efeitos da temperatura febril na presença de LPS, o papel exercido pela temperatura febril se mostrou mais relacionado com a modulação da resposta do que com o aumento ou diminuição de sua intensidade. Observamos que a febre potencializou uma resposta tipo Th1, através do aumento da produção de IFN-y nas culturas alogenêicas e uma maior proporção de linfócitos $\mathrm{T} \mathrm{CD8}^{+}$nessas culturas, indicada pela razão calculada da porcentagem das subpopulações de linfócitos $T$ nas culturas alogenêicas. Os resultados encontrados em nossos estudos são corroborados por outros dados da literatura, que também indicam um papel modulador da febre sobre a resposta de DCs a um estímulo microbiano. Em um trabalho recente realizado por Hatzfeld-Charbonnier et al. (2007) também foi encontrado que DCs humanas estimuladas com LPS induziam aumentada produção de IFN-y em co-culturas com linfócitos T. Além 
disso, Peng et al. (2006) mostraram que DCs estimuladas concomitantemente com estímulo microbiano e temperatura febril apresentavam um aumento da resposta Th1 e produção de IL-12. Embora nossos dados tenham mostrado um aumento na produção de IFN-y nas culturas alogenêicas, não fomos capazes de identificar um aumento na produção de IL-12 por essas culturas, mesmo considerando o estímulo com LPS. Do mesmo modo, também não observamos tal aumento na análise de citocinas nas culturas de DCs após o estímulo com temperatura febril isoladamente. A razão para a ausência de tal detecção pode estar relacionada a diversos fatores. Uma possibilidade é de que a cinética de produção das citocinas não tenha permitido a detecção das variações nas culturas. Nas co-culturas alogenêicas, detectamos apenas o aumento da produção de IFN-Y e aumento da proporção de linfócitos $T C D 8^{+}$, que são secundários à produção de IL-12 (PENG et al., 1996; BHARDWAJ et al., 1996; HEUFLER et al., 1996; HILKENS et al., 1997). É possível que no momento do ensaio, a IL-12 liberada já havia sido consumida pelas células. Também não houve um aumento significativo da produção de IL-10 após o estímulo com LPS, o que é descrito em muitos trabalhos. No entanto, diversos outros trabalhos também não encontraram tal aumento, sugerindo que esta resposta pode ser variável, de acordo com as condições de geração de DCs (JIANG et al., 2002; QI; DENNING; SOONG, 2003). Quanto ao estímulo febril, não foram encontradas diferenças significativas na produção de IL-10 entre as culturas estimuladas com LPS sozinho ou em conjunto com a temperatura febril. A produção de IL-4 foi detectada apenas em alguns indivíduos. Interessante notar que em alguns indivíduos, houve aumento da produção desta citocina após estímulo com LPS, a qual foi reduzida frente à adição do estímulo com temperatura febril. Essa observação corrobora os dados encontrados, mencionados anteriormente, que sugerem a modulação da resposta para um fenótipo Th1, induzida pela temperatura febril. Quanto ao TNF- $\alpha$, houve detecção de um aumento após o estímulo com LPS, conforme esperado, mas não houve variação frente ao estímulo concomitante com a temperatura febril.

Assim como observado em nosso estudo, Peng et al. (2006) também encontraram um sinergismo na indução de resposta Th1 induzido pelo estímulo 
com temperatura febril e seus resultados indicam uma participação da molécula CD40, que está envolvida na diferenciação de linfócitos $T \mathrm{CD}^{+}$ (SCHOENBERGER et al., 1998; TOE et al., 1998; CLARKE, 2000; KELLEHER e BEVERLY, 2001). Como já mencionado anteriormente, em nossos estudos realizados com a temperatura febril sozinha, a expressão de CD40 também foi modulada. No entanto, quando analisamos a expressão de CD40 nas células dendríticas estimuladas pelo calor juntamente com LPS, não observamos um aumento na sua expressão. Na verdade, ao analisarmos de um modo mais cuidadoso, observamos que alguns indivíduos apresentam uma marcante diminuição da expressão da molécula CD40. Interessantemente, esse fenômeno também é descrito nos estudos de Peng et al. (2006) e os dados revelados em seu trabalho indicam que essa diminuição da expressão se deve à co-localização de CD40 e HSP70 endógena na membrana celular, o que mascararia a ligação de anticorpos anti-CD40 para a citometria de fluxo. No presente estudo, não tivemos a oportunidade de avaliar se em nossas células também ocorre uma colocalização entre CD40 e HSP70. Além disso, quando avaliamos a expressão de HSP70 de membrana nas superfícies das células, não encontramos diferença na expressão dessas moléculas. No entanto, uma vez que a temperatura febril isoladamente exerceu um efeito sobre a expressão da molécula CD40, e frente ao tipo de resposta induzida, ou seja, aumento da proporção de linfócitos T CD8 ${ }^{+}$e IFN-y, a indução da co-localização, encontrada por Peng et al (2006), poderia ser o mecanismo envolvido na resposta encontrada em nosso estudo.

Um outro aspecto de nosso trabalho que deve ser discutido é o fato de nossos resultados apresentarem apenas leves diferenças, embora significativas, quando analisadas no conjunto de indivíduos. Quando avaliamos os dados individualmente, observamos que alguns de nossos indivíduos não apresentaram resposta, enquanto que outros apresentam uma resposta bastante significativa. É bastante provável que a resposta a esses estímulos seja variável, de acordo com a população estudada, com alguns indivíduos apresentando uma resposta mais proeminente do que outros. Corroborando essa hipótese, trabalhos realizados com diferentes linhagens de animais também demonstram uma variação de resposta 
inflamatória frente à hipertermia e/ou estímulos microbianos. Ostberg et al. (2000) mostraram um efeito linhagem-específico da hipertermia sobre a resposta inflamatória, com um aumento significativo da produção de TNF-a e IL-6 em camundongos BALB/c, enquanto não houve diferença na produção da citocina por camundongos C57BL/6. Além disso, a expressão de TLRs em DCs é diferente entre essas duas linhagens, causando uma produção distinta de citocinas em resposta ao estímulo com LPS (LIU et al., 2002). Portanto, é interessante que por vezes não analisemos os dados apenas no contexto de uma população única, mas de subgrupos de indivíduos, considerando que estamos diante de uma população bastante diversa e heterogênea. Tal situação é perfeitamente explicável dentro da grande variabilidade de nossa população e ainda mais quando consideramos a diversidade de resposta que pode ser gerada pelas células dendríticas (OSTBERT et al., 2000; LIU, 2002). Portanto, é imprescindível termos sempre em mente que quando estudamos seres humanos estamos lidando com diversas subpopulações (sejam elas ambientais, genéticas, comportamentais) e muitas vezes torna-se difícil a homogeneização de tais resultados. Além disso, a dificuldade de encontrarmos uma associação simplificada ou direta dentre os dados encontrados em nossos estudos pode estar relacionada à complexidade da resposta imune frente a diferentes estímulos e microambientes locais.

Contudo, em conjunto com as observações encontradas em animais ectotérmicos (KLUGER; RINGLER; ANVER, 1975; COVERT e REYNOLDS, 1977) e camundongos (JIANG et al., 2000), a relevância de mecanismos de aquecimento exógeno na sobrevivência contra infecções não pode ser negada (OSTBERG; PATEL; REPASKY, 2000). No entanto, devemos ser cuidadosos ao extrapolarmos os dados encontrados em nossos estudos, assim como os demais trabalhos com hipertermia in vitro ou in vivo publicados, e não compará-los diretamente aos fenômenos ocorridos em um processo natural de febre. Por exemplo, o tratamento com hipertermia aplicado externamente in vivo, "contorna" os eventos neurológicos, imunológicos e bioquímicos que normalmente levam a febre (KLUGER, 1991). Além disso, o estímulo febril isolado, aqui utilizado para avaliar sua possível aplicação em protocolos terapêuticos, não representa uma 
situação fisiológica, pois a febre está associada à presença de um fator desencadeador, como no caso de uma infecção e consequentemente "sinais de perigo" que se ligam a TLRs. No entanto, os dados encontrados em nossos estudos sugerem indícios de que a hipertermia pode ser auxiliar em protocolos clínicos terapêuticos, assim que for alcançado um melhor entendimento desses fenômenos e da variabilidade associada.

O mecanismo pelo qual a febre exerce os efeitos encontrados em nossos estudos não pôde ser elucidado ainda, mas os dados são indicativos de que esteja relacionado com a interação da molécula CD40, já que ela parece ser o elo de ligação entre todos os fenômenos encontrados em nossas investigações e os dados da literatura. Diante disso, a avaliação da interação entre CD40 e o aumento da temperatura, com possível participação de TLRs pode ser o caminho para o melhor entendimento dos mecanismos envolvidos na interação entre a febre e o sistema imune, assim como de seu papel na modulação da resposta a patógenos ou outros estímulos. 


\section{CONCLUSÕES}

Observamos que:

- A temperatura febril não afetou a viabilidade, atividade endocítica e secreção de citocinas TNF- $\alpha, \quad \mathrm{LL}-10$ e IL-12p70 por DCs ao final da cultura de diferenciação/maturação.

- Dentre as moléculas coestimuladoras analisadas, foi observado um aumento da expressão de CD40 em DCs estimuladas com temperatura febril isoladamente, mas esse aumento não foi observado em DCs coestimuladas com LPS. Não foram observadas variações significativas na expressão de CD80 e CD86 por DCs estimuladas com temperatura febril isoladamente ou em conjunto com LPS.

- A expressão de HSP70 na membrana de DCs não apresentou variação frente aos diferentes estímulos.

- A análise da atividade aloestimuladora de DCs mostrou que as células estimuladas com temperatura febril isoladamente apresentou aumento da atividade aloestimuladora, mas tal aumento não foi acompanhado de variação na produção de citocinas em co-cultura. DCs estimuladas com LPS e temperatura febril induziram aumento da produção de IFN-y e foi observada uma maior proporção de linfócitos T CD8+ nas co-culturas alogenêicas, sugerindo o favorecimento de um fenótipo tipo Th1.

Em conjunto, os resultados indicam que a temperatura febril pode modular o fenótipo e a função de DCs humanas derivadas de monócitos sangüíneos. 


\section{REFERÊNCIAS BIBLIOGRÁFICAS}

ADEMA, G.J. et al. A dendritic-cell-derived C-C chemokine that preferentially attracts naive T cells. Nature, v. 387, p. 713-717, 1997.

ALBERT, M.L.; JEGATHESAN, M.; DARNELL, R.B. Dendritic cell maturation is required for the cross-tolerization of CD8+ T cells. Nat. Immunol., v. 2, p. 10101017, 2001.

ARDAVIN, C. et al. Origin and differentiation of dendritic cells. Trends Immunol., v. 22, p. 691-700, 2001.

ARDAVIN, C. Dendritic cell heterogeneity: developmental plasticity and functional diversity. Semin. Immunol., v. 17, p. 251-252, 2005.

ATANACKOVIC, D. et al. 41.8 degrees $\mathrm{C}$ whole body hyperthermia as an adjunct to chemotherapy induces prolonged $\mathrm{T}$ cell activation in patients with various malignant diseases. Cancer Immunol. Immunother., v. 51, p. 603-613, 2002.

BANCHEREAU, J.; STEINMAN, R.M. Dendritic cells and the control of immunity. Nature, V. 19, p. 245-252, 1998.

BANCHEREAU, J. et al. Immunobiology of dendritic cells. Annu. Rev. Immunol.,v.18, p. 767-811, 2000.

BARBUTO, J.A. et al. Dendritic cell-tumor cell hybrid vaccination for metastatic cancer. Cancer. Immunol. Immunother., v. 53, p. 1111-1118, 2004.

BHARDWAJ, N. et al. IL-12 in conjunction with dendritic cells enhances antiviral CD8+ CTL responses in vitro. Clin. Invest., v. 98, n. 3, p. 715-722, 1996.

BARTON, G.M.; MEDZHITOV, R. Toll-like receptor signaling pathways. Science, v. 300, n. 5652, p. 1524-5252, 2003.

BASU, S. et al. Necrotic but not apoptotic cell death releases heat shock proteins, which deliver a partial maturation signal to dendritic cells and activate the NFkappa B pathway. Int. Immunol., v. 12, n. 11, p. 1539-1546, 2000.

BAUMANN, H.; GAULDIE, J. The acute phase response. Immunol. Today, v. 5, p. 74-80, 1994.

\footnotetext{
De acordo com:

ASSOCIAÇÃO BRASILEIRA DE NORMAS TÉCNICAS. NBR 6023: Informação e documentação: referências: elaboração. Rio de Janeiro, 2002.
} 
BELZ, G.T.; HEATH, W.R.; CARBONE, F.R. The role of dendritic cell subsets in selection between tolerance and immunity. Immunol. Cell Biol., v 80. n. 5, p. 463468, 2002.

BERNHEIM, H.A. et al. Effects of fever on host defense mechanisms after infection in the lizard Dipsosaurus dorsalis. Br. J. Exp. Pathol., v. 59, n. 1, p. 76-84, 1978.

BROSSART, P. et al. Dendritic cells in cancer vaccines. Exp. Hematol., v. 29, n. 11, p. 1247-1255, 2001.

CARRENO, B.M.; COLLINS, M. The B7 family of ligands and its receptors: new pathways for costimulation and inhibition of immune responses. Annu. Rev. Immunol., v. 20, n. 4, p. 29-53, 2002.

CAUX, C. et al. Activation of human dendritic cells through CD40 cross-linking. J. Exp. Med., v. 180, n. 4, p. 1263-1272, 1994.

CAUX, C. et al. CD34+ hematopoietic progenitors from human cord blood differentiate along two independent dendritic cell pathways in response to GMCSF+TNF alpha. Adv. Exp. Med. Biol., v. 417, p. 21-25, 1997.

CAUX, C. et al. Dendritic cell biology and regulation of dendritic cell trafficking by chemokines. Springer Semin. Immunopathol., v. 22, n. 4, p. 345-69, 2000.

CHEN, X.Z. et al. Heat-shock protein 70 may be a putative endogenous ligand of Toll-like receptor-4 of human monocytes. Zhonghua Yi Xue Za Zhi, v. 85, n. 7, p. 483-486, 2005.

CHIRICO, W.J.; WATERS, M.G.; BLOBEL, G. 70K heat shock related proteins stimulate protein translocation into microsomes. Nature, v. 332, n. 6167, p. 805$101,1988$.

CLARKE, S.R.The critical role of CD40/CD40L in the CD4-dependent generation of CD8+ T cell immunity. J. Leukoc. Biol., v. 67, n. 5, p. 607-614, 2000.

COVERT, J.B.; REYNOLDS, W.W. Survival value of fever in fish. Nature, v. 267, n. 5606, 43-45, 1977.

CUDDY, M.L. The effects of drugs on thermoregulation. AACN Clin. Issues., v. 15, n. 2, p. 238-253, 2004.

DEL HOYO, G.M. et al. Characterization of a common precursor population for dendritic cells. Nature, v. 415, n. 6875, p. 1043-1047, 2002.

DOWNING, J.F.; TAYLOR, MW. The effect of in vivo hyperthermia on selected lymphokines in man. Lymphokine Res., v. 6, n. 2, p. 103-109, 1987. 
DUBSKY, P. et. al, Human dendritic cell subsets for vaccination. J. Clin. Immunol., v. 25, n. 6, p. 551-572, 2005.

ENGERING, A.J. et al. Mannose receptor mediated antigen uptake and presentation in human dendritic cells. Adv. Exp. Med. Biol., v. 417, p. 183-187, 1997.

FLACHER, V. et al. Human Langerhans cells express a specific TLR profile and differentially respond to viruses and Gram-positive bacteria. J. Immunol., v. 177, n. 11, p. 7959-7967, 2006.

FREEDMAN, A.S. et al. Selective induction of B7/BB-1 on interferon-gamma stimulated monocytes: a potential mechanism for amplification of $\mathrm{T}$ cell activation through the CD28 pathway. Cell. Immunol., v. 137, p. 429-437, 1991.

GUERMONPREZ, $P$. et al. Antigen presentation and $T$ cell stimulation by dendritic cells. Annu. Rev. Immunol., v. 20, n. 4, p. 621-667, 2002.

HAJTO, T. Effect of in vivo hyperthermia on human natural killer cells. Clin. Trials J., v. 22, p. 514-520, 1985.

HART, D.N. Dendritic cells: unique leukocyte populations which control the primary immune response. Blood, v. 90, n. 9, p. 3245-3287, 1997.

HATHCOCK, K.S. et al. Comparative analysis of B7-1 and B7-2 costimulatory ligands: expression and function. J. Exp. Med., v. 180, n. 2, p. 631-640, 1994.

HATZFELD-CHARBONNIER, A.S. et al. Influence of heat stress on human monocyte-derived dendritic cell functions with immunotherapeutic potential for antitumor vaccines. J. Leukoc. Biol., v. 81, n. 5, p. 1179-1187, 2007.

HEUFLER, C. et al. Interleukin-12 is produced by dendritic cells and mediates $T$ helper 1 developmentas well as interferon-gamma production by Thelper 1 cells. Eur. J. Immunol., v. 26, n. 3, p. 659-668, 1996.

HILKENS, C.M. et al. Human dendritic cells require exogenous interleukin-12inducing factors to directthe development of naive T-helper cells toward the Th1 phenotype. Blood, v. 90, n. 5, p. 1920-1926, 1997.

HSU, F.J. et al. Vaccination of patients with B-cell lymphoma using autologous antigen-pulsed dendritic cells. Nat. Med., v. 2, n. 1, p. 52-58, 1996.

HOCHREIN, H.; O'KEEFFE, M. Dendritic cell subsets and toll-like receptors. Handb. Exp. Pharmacol., v. 183, p. 153-179, 2008. 
HUANG, Y.H.; HAEGERSTRAND, A.; FROSTEGARD, J. Effects of in vitro hyperthermia on proliferative responses and lymphocyte activity. Clin. Exp. Immunol., v. 103, n. 1, p. 61-66, 1996.

HUANG, Y.M. et al. Phenotypic and functional properties of dendritic cells isolated from human peripheral blood in comparison with mononuclear cells and $\mathrm{T}$ cells. Scand. J. Immunol., v. 49, n. 2, p. 177-183, 1999.

IZUMI, A.; KOGA, S.; MAETA, M. Effects of in vitro hyperthermia on murine and human lymphocytes. Cancer, v. 51, n. 11, p. 2061-2065, 1983.

ITO, A. et al. Heat-inducible TNF-alpha gene therapy combined with hyperthermia using magnetic nanoparticles as a novel tumor-targeted therapy. Cancer Gene Ther., v. 8, n. 9, p. 649-654, 2001.

JIANG, Q. et al. Febrile core temperature is essential for optimal host defense in bacterial peritonitis. Infect. Immun., v. 68, n. 3, p. 1265-1270, 2000.

JIANG, H.R. et al. Secretion of interleukin-10 or interleukin-12 by LPS-activated dendritic cells is critically dependent on time of stimulus relative to initiation of purified DC culture. J. Leukoc. Biol., v. 72, p. 978-985, 2002.

KATO, M. et al. Expression of multilectin receptors and comparative FITC-dextran uptake by human dendritic cells. Int. Immunol., v. 12, n. 11, p. 1511-1519, 2000.

KAISHO, T.; AKIRA, S. Toll-like receptors as adjuvant receptors. Biochim. Biophys. Acta., v. 1589, n. 1, p. 1-13, 2002.

KELLEHER, M.; BEVERLEY, P.C. Lipopolysaccharide modulation of dendritic cells is insufficient to mature dendritic cells to generate CTLs from naive polyclonal CD8+ T cells in vitro, whereas CD40 ligation is essential. J. Immunol., v. 167, n. 11 , p. 6247-6255, 2001.

KLUGER, M.J.; RINGLER, D.H; ANVER, M.R. Fever and survival. Science, v. 188, n. 4184, p. 166-168, 1975.

KLUGER, M. J. Fever: role of pyrogens and cryogens. Physiol. Rev., v. 71, n. 1, p. 93-127, 1991.

LADERACH, D.; WESA, A.; GALY, A. 4-1BB-ligand is regulated on human dendritic cells and induces the production of IL-12. Cell. Immunol., v. 226, n. 1, p. 37-44, 2003.

LEON, B.; ARDAVIN, C. Monocyte-derived dendritic cells in innate and adaptive immunity. Immunol. Cell Biol., v. 86, n. 4, p. 320-324, 2008. 
LIU, T. et al., Differences in expression of toll-like receptors and their reactivities in dendritic cells in BALB/c and C57BL/6. Infect. Immun., v. 70, n. 12, p. 6638-6645, 2002.

MACDONALD, K.P. et al. Characterization of human blood dendritic cell subsets. Blood, v. 100, n. 13, p. 4512-4520, 2002.

MCMILLAN, D.R. et al. Targeted disruption of heat shock transcription factor 1 abolishes thermotolerance and protection against heat-inducible apoptosis. J. Biol. Chem., v. 273, n. 13, p. 7523-7258, 1998.

MCILROY, D. et al. Infection frequency of dendritic cells and CD4+ T lymphocytes in spleens of human immunodeficiency virus-positive patients. J. Virol., v. 69, n. 8, p. 4737-4745, 1995.

MEJIA, R.; GOMEZ-EICHELMANN, M.C.; FERNANDEZ, M.S. Membrane fluidity of Escherichia coli during heat-shock. Biochim. Biophys. Acta, v. 1239, n. 2, p. 195-200, 1995.

MOSELEY, P. Stress proteins and the immune response. Immunopharmacology, v. 48, n. 3, p. 299-302, 2000.

MUZIO, M. et al. Differential expression and regulation of toll-like receptors (TLR) in human leukocytes: selective expression of TLR3 in dendritic cells. J. Immunol., v. 164, n. 11, p. 5998-6004, 2000.

NAUTS, H.C. Bacteria and cancer--antagonisms and benefits. Cancer Surv., v. 8, n. 4, p. 713-723, 1989.

NAUTS, H.C.; MCLAREN, JR. Coley Toxins - the first century. Adv. Exp. Med. Biol., v. 268, n. 483-500, 1990.

NESTLE, F.O. et al. Vaccination of melanoma patients with peptide- or tumor lysate-pulsed dendritic cells. Nat. Med., v. 4, n. 3, p.328-332, 1998.

NEVES, A.R. Estudo da diferenciação in vitro de células dendríticas derivadas de monócitos sangüíneos: análise dos efeitos de diferentes condições de cultura no fenótipo imunoestimulador das células. 95f. Dissertação (Mestrado em Imunologia) - Instituto de Ciências Biomédicas, Universidade de São Paulo, São Paulo, 2003.

NEVES, A.R. et al. Dendritic cells derived from metastatic cancer patients vaccinated with allogeneic dendritic cell-autologous tumor cell hybrids express more CD86 and induce higher levels of interferon-gamma in mixed lymphocyte reactions. Cancer Immunol. Immunother., v. 54, n. 1, p. 61-66, 2005. 
NICOLETTI, I. et al. A rapid and simple method for measuring thymocyte apoptosis by propidium iodide staining and flow cytometry. J. Immunol. Methods., v.139, n. 2, p. 271-279, 1991.

NOESSNER, E. Thermal stress-related modulation of tumor cell physiology and immune responses. Cancer Immunol. Immunother., v. 55, n. 3, p. 289-291, 2006.

NUSSENZWEIG, M.C.; STEINMAN, R.M. Contribution of dendritic cells to stimulation of the murine syngeneic mixed leukocyte reaction. J. Exp. Med., v. 51, n. 5, p. 1196-1212, 1980.

OSTBERG, J.R. et al Regulatory effects of fever-range whole-body hyperthermia on the LPS-induced acute inflammatory response. J. Leukoc. Biol., v. 68, n. 6, p. 815-820, 2000.

OSTBERG, J.R.; PATEL, R.; REPASKY, E.A. Regulation of immune activity by mild (fever-range) whole body hyperthermia: effects on epidermal Langerhans cells. Cell Stress Chaperones, v. 5, n. 5, p. 458-461, 2000.

OSTBERG, J.R. et al. Regulatory potential of fever-range whole body hyperthermia on Langerhans cells and lymphocytes in an antigen-dependent cellular immune response. J, Immunol., v. 167, n. 5, p. 2666-2670, 2001.

OSTBERG, J.R; KABINGU, E; REPASKY, EA.Thermal regulation of dendritic cell activation and migration from skin explants. Int. J. Hyperthermia., v. 19, n. 5, p. 520-533, 2003.

OSTBERG, J.R; REPASKY, E.A. Emerging evidence indicates that physiologically relevant thermal stress regulates dendritic cell function. Cancer Immunol. Immunother., v. 55, n. 3, p. 292-298, 2006.

O'SULLIVAN, B; THOMAS, R. CD40 and dendritic cell function. Crit. Rev. Immunol., v. 23, n. 1, p. 83-107, 2003.

PARDOLL, D.M. Spinning molecular immunology into successful immunotherapy. Nat. Rev. Immunol., v. 2, n. 4, p. 227-238, 2002.

PENG, X. et al. Accessory signaling by CD40 for T cell activation: induction of Th1 and Th2cytokines and synergy with interleukin-12 for interferon-gamma production. Eur. J. Immunol., v. 26, n. 7, p. 1621-1627, 1996.

PENG, J.C. et al. Monocyte-derived DC primed with TLR agonists secrete IL$12 \mathrm{p} 70$ in a CD40-dependent manner under hyperthermic conditions. $\mathbf{J}$. Immunother., v. 29, n. 6, 606-615, 2006. 
PULENDRAN, B.; TANG, H.; DENNING, T.L. Division of labor, plasticity, and crosstalk between dendritic cell subsets. Curr. Opin. Immunol., v. 20, n. 1, p. 6167, 2008.

QI, H.; DENNING, T.L; SOONG, L. Differential induction of interleukin-10 and interleukin-12 in dendritic cells by microbial toll-like receptor activators and skewing of T-cell cytokine profiles. Infect. Immun., v. 71, n. 6, p. 3337-3342, 2003.

QUAH, B.J.; O'NEILL, H.C. Maturation of function in dendritic cells for tolerance and immunity. J. Cell Mol. Med., v. 9, n. 3, p. 643-654, 2005.

RANDOLPH, G.J.; OCHANDO, J.; PARTIDA-SANCHES, S. Migration of dendritic cell subsets and their precursors. Annu. Rev. Immunol., v. 26, p. 293-316, 2008.

REIS E SOUSA, C. Activation of dendritic cells: translating innate into adaptive immunity. Curr. Op. Immunol., v. 16, n. 1, p. 21-25, 2004.

ROMANI, N. Generation of mature dendritic cells from human blood. An improved method with special regard to clinical applicability. J. Immunol. Methods, v. 196, n. 2, p. 137-151, 1996.

SALLUSTO, F. et al. Distinct patterns and kinetics of chemokine production regulate dendritic cell function. Eur. J. Immunol.,. 29, n. 5, 1617-1625, 1999.

SANCHEZ, P.J. et al. Combined TLR/CD40 stimulation mediates potent cellular immunity by regulating dendritic cell expression of CD70 in vivo. J. Immunol., v. 178, n. 3, p. 1564-1572, 2007.

SAXON, A.; FELDHAUS, J.; ROBINS, R.A. Single step separation of human T and $B$ cells using AET treated srbc rosettes. J. Immunol. Methods., v. 12, n. 3-4, p. 285-288, 1976.

SCHENDEL, D.J. Dendritic cell vaccine strategies for renal cell carcinoma. Expert. Opin. Biol. Ther., v. 7, n. 2, p. 221-32, 2007.

SCHOENBERGER, S. P. et al. T-cell help for cytotoxic T lymphocytes is mediated by CD40-CD40L interactions. Nature, v. 393, n. 6684, p. 480-483, 1998.

TOES, R.E. et al. CD40-CD40 Ligand interactions and their role in cytotoxic T lymphocyte priming and anti-tumor immunity. Semin. Immunol., v. 10, n.6, p. 443448, 1998.

TODRYK S.M. et al., Heat shock proteins refine the danger theory. Immunology, v. 99, n. 3, p. 334-337, 2000.

SCHUURHUIS, D.H. et al. Ins and outs of dendritic cells. Int. Arch. Allergy Immunol., v. 140, n. 1, p. 53-72, 2006. 
SHEN, R.N. et al. Influence of elevated temperature on natural killer cell activity, lymphokine-activated killer cell activity and lectin-dependent cytotoxicity of human umbilical cord blood and adult blood cells. Int. J. Rad. Oncol. Biol. Phys., v. 29, n. 4, p. 821-826, 1994.

SHORTMAN, K.; LIU, Y.J. Mouse and human dendritic cell subtypes. Nat. Rev. Immunol., v. 2, n. 3, p. 151-161, 2002.

SITNICKA, E.W.; OLSZEWSKI, W.L.; LUKOMSKA, B. Influence of whole-body hyperthermia on natural cytotoxicity of liver blood-borne sinusoidal cells. Int. $\mathbf{J}$. Hyperthermia, v. 9, n. 5, p. 731-743, 1993.

SLAVIK, J.M.; HUTCHCROFT, J.E.; BIERER, B.E. CD28/CTLA-4 and CD80/CD86 families: signaling and function. Immunol. Res., v. 19, n. 1, p. 1-24, 1999.

SOZZANI, S. et al. Differential regulation of chemokine receptors during dendritic cell maturation: a model for their trafficking properties. J. Immunol., v. 161, n. 3, p. 1083-1086, 1998.

STEINMAN, R.M.; COHN, Z.A. Identification of a novel cell type in peripheral lymphoid organs of mice. I. Morphology, quantitation, tissue distribution. J. Exp. Med., v. 137, n. 5, p. 1142-1162, 1973.

STEINMAN, R.M.; COHN, Z.A. Identification of a novel cell type in peripheral lymphoid organs of mice. II. Functional properties in vitro. J. Exp. Med., v. 13, n. 6, p. 380-397, 1974.

STEINMAN, R.M.; LUSTIG, D.S.; COHN, Z.A. Identification of a novel cell type in peripheral lymphoid organs of mice. 3. Functional properties in vivo. J. Exp. Med., v. 139, n. 2, p. 1431-1445, 1974.

STEINMAN, R.M.; WITMER, M.D. Lymphoid dendritic cells are potent stimulators of the primary mixed leukocyte reaction in mice. Proc. Natl. Acad. Sci. U. S. A., v. 75, n. 10, p. 5132-5136, 1978.

TAILLEUX, L. et al. DC-SIGN is the major Mycobacterium tuberculosis receptor on human dendritic cells. J. Exp. Med., v. 197, n. 1, p. 121-127, 2003.

TAN, J.K.; O'NEILL, H.C. Maturation requirements for dendritic cells in T cell stimulation leading to tolerance versus immunity. J. Leukoc. Biol., v. 78, n. 2, p. 319-324, 2005.

TARABAN, V.Y.; ROWLEY, T.F.; AL-SHAMKHANS, A. Cutting edge: a critical role for CD70 in CD8 T cell priming by CD40-licensed APCs. J. Immunol., v. 173, n. 11, p. 6542-6546, 2004. 
TAKEDA, K.; AKIRA, S. Regulation of innate immune responses by Toll-like receptors. Jpn. J. Infect. Dis., v. 54, n. 6, p. 209-219, 2001.

TAKEDA, K.; KAISHO, T.; AKIRA, S. Toll-like receptors. Annu. Rev. Immunol., v. 21, n. 19, p. 335-376, 2003.

TOURNIER, J.N. et al. Fever-like thermal conditions regulate the activation of maturing dendritic cells. J. Leukoc. Biol., v. 73, n. 4, p. 493-501, 2003.

STEINMAN, R.M.; WITMER, A.G. et al. Tumor-derived heat shock protein 70pulsed dendritic cells elicit tumor-specific cytotoxic $T$ lymphocytes (CTLs) and tumor immunity. Cancer Sci., v. 95, n. 3, p. 248-253, 2004.

VAN BRUGGEN, I.; ROBERTSON, T.A.; PAPADIMITRIOU, J.M. The effect of mild hyperthermia on the morphology and function of murine resident peritoneal macrophages. Exp. Mol. Pathol., v. 55, n. 2, p. 119-134, 1991.

VAN VLIET, S.J.; GARCIA-VALLEJO, J.J.; VAN KOOYK, J. Dendritic cells and Ctype lectin receptors: coupling innate to adaptive immune response. Immunol. Cell Biol., 2008 In press.

VANDENABEELE, S. et al. Human thymus contains 2 distinct dendritic cell populations. Blood, v. 97, n. 6, p. 1733-1741, 2001.

VERHASSELT, V. et al. Bacterial lipopolysaccharide stimulates the production of cytokines and the expression of costimulatory molecules by human peripheral blood dendritic cells: evidence for a soluble CD14-dependent pathway. $\mathbf{J}$. Immunol., v. 158, n. 6, p. 2919-2925, 1997.

VISINTIN, A. et al. Regulation of Toll-like receptors in human monocytes and dendritic cells. J. Immunol., v. 166, n. 1, p. 249-255, $2001 .$.

WALSH, A.; EDWARDS, H. Management of childhood fever by parents. J. Adv. Nurs., v. 54, n. 2, p. 217-227, 2006.

WANG, X.Y.; OSTBERG, J.R.; REPASKY, E.A.. Effect of fever-like whole-body hyperthermia on lymphocyte spectrin distribution, protein kinase $C$ activity, and uropod formation. J. Immunol., v. 162, n. 6, p. 3378-3387, 1999.

YAN, X. et al. Fever range temperature promotes TLR4 expression and signaling in dendritic cells. Life Sci., v. 80, n. 4, p. 307-313, 2007.

YANAGIHARA, S. et al. EBI1/CCR7 is a new member of dendritic cell chemokine receptor that is up-regulated upon maturation. J. Immunol., v. 161, n. 6, p. 30963102, 1998. 
YOSHIOKA, $\mathrm{H}$. et al. The influence of hyperthermia in vitro on the functions of peritoneal macrophages in mice. Jpn. J. Surg., v. 20, n. 1, p. 119-122, 1990.

YU, Z. et al. Activation of antitumor cytotoxic T lymphocytes by fusion of patientderived dendritic cells with autologous osteosarcoma. Exp. Oncol., v. 27, n. 4, p. 273-278, 2005.

ZANKER, K.S.; LANGE, J. Whole body hyperthermia and natural killer cell activity. Lancet, v. 1, n. 8280, p. 1079-1080, 1982.

ZHANG, Y. et al. Dendritic cells fused with allogeneic breast cancer line induce tumor antigen-specific CTL responses against autologous breast cancer cells. Breast Cancer Res. Treat., v. 105, n. 3, p. 277-286, 2007.

ZHENG, $H$. et al. Heat shock factor 1 -independent activation of dendritic cells by heat shock: implication for the uncoupling of heat-mediated immunoregulation from the heat shock response. Eur. J. Immunol., v. 33, n. 6, p. 1754-1762, 2003.

ZHENG, Y. et al. CD86 and CD80 differentially modulate the suppressive function of human regulatory T cells. J. Immunol., v. 172, n. 5, p. 2778-2784, 2004.

ZHOU, L.J.; TEDDER, T.F. CD14+ blood monocytes can differentiate into functionally mature CD83+ dendritic cells. Blood, v. 93, n. 6, p. 2588-2592, 1996. 


\section{ANEXO}

\section{Tampão hipotônico HSF}

0,1\% de Triton X-100 (Sigma-Aldrich)

$0,1 \%$ de Citrato de Sódio

$50 \mu \mathrm{g} / \mathrm{mL}$ de iodeto de propídeo (BD Pharmingen ${ }^{\mathrm{TM}}$ )

Tampão PBS - Salina tamponada com Fosfato (Solução estoque 10x concentrada)

$\mathrm{Na}_{2} \mathrm{PO}_{4}$ (Sigma-Aldrich) $\quad 14,2 \mathrm{~g}$

$\mathrm{NaH}_{2} \mathrm{PO}_{4}$ (Sigma-Aldrich) $\quad 3,6 \mathrm{~g}$

HCL (Sigma-Aldrich) $\quad 82,0 \mathrm{~g}$

$\mathrm{H}_{2} \mathrm{O} \quad$ QSP $1000 \mathrm{ml}$

\section{Tampão PBS -BSA}

Tampão PBS contendo 0,1\% de albumina sérica bovina (BSA) (Gibco Life Technologies)

\section{Tampão para Citometria}

PBS $1000 \mathrm{ml}$

Albumina sérica bovina (Gibco Life $\quad 5,0 \mathrm{~g}$ Technologies)

Azida Sódica (Synth, Diadema, SP Brasil) 1,0 mg 
Tampão de Lise de Hemácias

Tampão Cloreto de Amônio

$\mathrm{NH} 4 \mathrm{Cl} \quad$ (Sigma-Aldrich) $\quad 2,14 \mathrm{~g}$

Água deionizada $\quad 250 \mathrm{~mL}$

Tampão Tris $(p H 7,3)$

Tris-base (hydroxymethyl aminometano) 1,025g

(Gibco Life Technologies)

Água deionizada $\quad 50 \mathrm{~mL}$

Preparar na hora do uso misturando-se 1 volume de Tris para 9 volumes de cloreto de amônio.

Tampões para ELISA

Tampão de Captura

pH 9,5

$\mathrm{NaHCO}_{3}$ (Sigma-Aldrich) $\quad 8,4 \mathrm{~g}$

$\mathrm{Na}_{2} \mathrm{CO}_{3}$ (Synth) $\quad 3,56 \mathrm{~g}$

$\mathrm{H}_{2} \mathrm{O} \quad$ QSP $1000 \mathrm{ml}$

Tampão PBS - ELISA

pH 7,0

$\mathrm{NaCl}$ (Sigma-Aldrich) $\quad 80 \mathrm{~g}$

$\mathrm{Na}_{2} \mathrm{HPO}_{4}$ (Sigma-Aldrich) $\quad 11,6 \mathrm{~g}$

$\mathrm{KH}_{2} \mathrm{PO}_{4}$ (Sigma-Aldrich) $\quad 2,0 \mathrm{~g}$

KCL (Sigma-Aldrich) $\quad 2,0 \mathrm{~g}$

$\mathrm{H}_{2} \mathrm{O} \quad$ QSP $1000 \mathrm{ml}$ 


\section{Tampão de Diluição}

PBS-ELISA contendo 10\% de Soro Bovino Fetal (Gibco Life Technologies)

Tampão de Lavagem

PBS-ELISA contendo 0,5\% de Tween 20 (Sigma-Aldrich) 